Maciej KOKOSZKO

Jolanta DYBAEA

Krzysztof JAGUSIAK

Zofia RZEŹNICKA*

\title{
CHLEB NIEODPOWIEDNI DLA CHRZEŚCIJAN: MORALNE ZALECENIA KLEMENSA ALEKSANDRYJSKIEGO W KONFRONTACJI Z NAUKOWYMI USTALENIAMI GALENA
}

\begin{abstract}
„Nawet tak proste pożywienie jak będący podstawowym pokarmem chleb starają się uczynić bardziej delikatnym, przesiewając specjalnie pszenną mąkę, by stał się on też zasługującą na naganę przyjemnością"'.
\end{abstract}

Tę negatywną opinię na temat nawyków żywieniowych niektórych mieszkańców egipskiej Aleksandrii okresu przełomu II i III w. po Chr. wyraził w jednym ze swoich dzieł Klemens, zwany Aleksandryjskim. W niniejszym tekście postaramy się udzielić odpowiedzi na pytanie, jaki konkretnie rodzaj chleba, spośród licznych gatunków spożywanych przez starożytnych Greków, mógł on mieć na myśli. W tym celu sięgniemy do pism współczesnego Klemensowi Galena, najwybitniejszego greckiego lekarza tamtych czasów.

* Dr hab. Maciej Kokoszko, prof. UŁ - kierownik Katedry Historii Bizancjum w Instytucie Historii na Wydziale Filozoficzno-Historycznym Uniwersytetu Łódzkiego; e-mail: mkokoszko@ komandor.pl; Dr Jolanta Dybała - absolwentka historii w Instytucie Historii na Wydziale Filozoficzno-Historycznym Uniwersytetu Łódzkiego; e-mail: j.dybala@vp.pl; Mgr Krzysztof Jagusiak - doktorant przy Katedrze Historii Bizancjum w Instytucie Historii na Wydziale Filozoficzno-Historycznym Uniwersytetu Łódzkiego; e-mail: krzysztof_jagusiak@o2.pl; Mgr Zofia Rzeźnicka doktorantka przy Katedrze Historii Bizancjum w Instytucie Historii na Wydziale Filozoficzno-Historycznym Uniwersytetu Łódzkiego; e-mail: zosia_pwp.historyk@wp.pl.

${ }^{1}$ Clemens Alexandrinus, Paedagogus II 1, 3, ed. C. Mondésert - H.I. Marrou, SCh 108, Paris

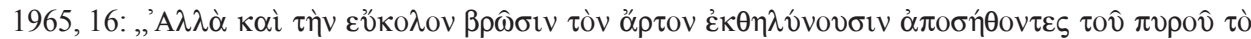

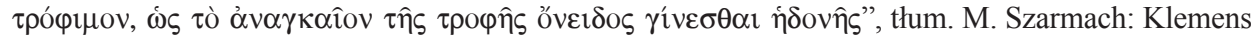
Aleksandryjski, Wychowawca, Toruń 2012, 84. W innym miejscy tej samej pracy (III 12, 90) Klemens, parafrazując tekst Księgi Izajasza, krytykuje spożywanie chleba wypiekanego z wybornej mąki. 
1. Życie i spuścizna literacka Klemensa Aleksandryjskiego. Starożytna metropolia aleksandryjska była, poczynając od III w. prz. Chr., największym ośrodkiem intelektualnym świata antycznego ${ }^{2}$. Funkcjonujące tutaj Muzeum i ogromna biblioteka pozwoliły na prowadzenie badań nad literaturą klasyczną oraz umożliwiły rozwój ówczesnych nauk - matematyki, astronomii i astrologii. Aleksandria zyskała sławę również jako centrum studiów medycznych, od kiedy, w 1. poł. III w. prz. Chr., działający tutaj Herofilos z Chalkedonu stworzył podwaliny pod rozwój anatomii i fizjologii opartych na sekcji ludzkich zwłok ${ }^{3}$. Czynny udział w miejscowym życiu umysłowym - głównie poprzez thumaczenie Septuaginty i działalność Filona (ok. 15 r. prz. Chr. - ok. 45 po Chr.) $)^{4}$ miała społeczność żydowska. Nic więc dziwnego, że wraz z nastaniem nowej wiary również jej wyznawcy chcieli skorzystać z potencjału, jaki wciąż tkwił w tym mieście. W tym celu do Aleksandrii przybył Klemens.

Tytus Flawiusz Klemens urodził się ok. 150 r. w rodzinie pogańskiej, zamieszkałej najprawdopodobniej w Atenach ${ }^{5}$. Naukę rozpoczął zapewne w rodzinnym mieście; by kształcić się dalej - już jako chrześcijanin - odbył szereg podróży, odwiedzając Italię, Syrię i Palestynę. Ok. roku 180 dotarł do Aleksandrii, gdzie spędził dwie kolejne dekady. Tutaj zetkną się z Pantajnosem,

${ }^{2}$ Więcej na temat tego miasta m.in. w: Ch. Haas, Alexandria in Late Antiquity. Topography and Social Conflict, Baltimore - London 1997, 19-44; A. Łukaszewicz, Egipt Greków i Rzymian, Warszawa 2006, 358-381; A. Świderkówna, Hellenika. Wizerunek epoki od Aleksandra do Augusta, Warszawa 2009, 131-156. O uprawianiu w nim nauki, w tym medycyny, np. w: V. Nutton, Ancient Medicine, New York - London 2004, 128-139; W. Sady, Czy uczeni aleksandryjscy byli naukowcami?, „Zagadnienia Naukoznawstwa” 43 (2007) fasc. 2, 293-302.

${ }^{3}$ Por. L. Russo, Zapomniana rewolucja. Grecka myśl naukowa a nauka nowoczesna, thum. I. Kania, Kraków 2005, 156-173. Na temat Herofilosa z Chalkedonu zob. J. Scarborough, Hērophilos of Khalkēdōn, w: The Encyclopedia of Ancient Natural Scientists. The Greek Tradition and its Many Heirs, ed. P. Keyser - G.L. Irby-Massie, Milton Park - New York 2008, 387-390.

${ }^{4}$ Por. M. Osmański, Filon z Aleksandrii, PEF III 440-449.

${ }^{5}$ Więcej na temat Klemensa m.in. w: Altaner, s. 277-284; J. Niemirska-Pliszczyńska, Wstęp, w: Klemens Aleksandryjski, Kobierce zapisków filozoficznych dotyczqcych prawdziwej wiedzy, thum., wstęp i kom. J. Niemirska-Pliszczyńska, t. 1, Warszawa 1994, VII-XI; J. Naumowicz, Wstęp, w: Klemens Aleksandryjski, Który człowiek bogaty może być zbawiony?, thum. J. Czuj, wstęp i oprac. J. Naumowicz; Pseudo-Klemens, Zachęta do wytrwatości, thum. i oprac. J. Naumowicz, Kraków Ząbki 1995, 5-7; H. von Campenhausen, Ojcowie Kościoła, tłum. K. Wierszyłowski, Warszawa 1998, 28-36; C. Vidal Manzanares, Klemens Aleksandryjski, w: tenże, Pisarze wczesnochrześcijańscy I-VII w., thum. E. Burska, Warszawa 2001², 116-117; J. Wojtczak, Klemens Aleksandrinos, w: Słownik pisarzy antycznych, red. A. Świderkówna, Warszawa 2001, 289-290; F. Drączkowski, Klemens Aleksandryjski, EK IX 98-99; M. Kowalewska - P. Szczur, Klemens Aleksandryjski, PEF V 637-641; J. Naumowicz, Środowisko aleksandryjskie i pisarze III wieku, LGS II 1079-1082; E. Osborn, Clement of Alexandria, Cambridge 2005. Niektórzy badacze przesuwają datę urodzin Klemensa o 10 lat później, zob. P. Karavites, Evil - Freedom - and the Road to Perfection in Clement of Alexandria, Leiden - Boston - Köln 1999, 4. 
twórcą szkoły, w której zgłębiano zarówno Ewangelię, jak i filozofię grec$\mathrm{ka}^{6}$. Klemens został uczniem Pantajnosa, następnie jego współpracownikiem, wreszcie zaś przejął po nim kierownictwo szkołą. Nie pozostał jednak w mieście do końca życia, lecz uszedł z niego przed prześladowaniami chrześcijan, które wybuchły za panowania Septymiusza Sewera w 202 lub 203 r. Schronił się wówczas w Kapadocji u swojego ucznia i przyjaciela Aleksandra, późniejszego biskupa Jerozolimy. Jego dalsze losy nie są znane. Zmarł ok. 10 lat po opuszczeniu Egiptu, gdyż w liście Aleksandra do Orygenesa z 215/216 r. wspomniany jest już jako zmarły. Choć Euzebiusz z Cezarei określa Klemensa mianem kapłana, kwesta ta jest w nauce wciąż dyskutowana ${ }^{7}$.

Klemensa uznaje się za pierwszego uczonego chrześcijańskiego, który mógł pochwalić się znajomością nie tylko Starego i Nowego Testamentu oraz niemal całej ówczesnej twórczości chrześcijańskiej, ale także greckiej literatury filozoficznej i klasycznej ${ }^{8}$. Jak podkreśla Peter Karavites, ośmielił się on, jak nikt przed nim, połączyć nową wiarę z kulturą hellenistyczna, zdawał sobie bowiem sprawę z faktu, iż chrześcijaństwo, chcąc się rozprzestrzenić i odnieść zwycięstwo, musi jako swojego pośrednika wykorzystać grecką edukacjęe. Osiągnięcia intelektualne starożytnych Greków Aleksandryjski Scholarcha pojmował więc jako „niezastąpione narzędzie ewangelizacji, pomoc $\mathrm{w}$ przygotowaniu do wiary, wsparcie $\mathrm{w}$ procesie doskonalenia chrześcijańskiego oraz narzędzie walki z herezjami"10.

\footnotetext{
${ }^{6}$ Więcej o Pantajnosie i jego szkole w: C. Vidal Manzanares, Panten, w: tenże, Pisarze wczesnochrześcijańscy I-VII w., s. 146; Naumowicz, Środowisko aleksandryjskie, s. 1079; Osborn, Clement of Alexandria, s. 19-24.

${ }^{7}$ Por. Altaner, s. 277; Naumowicz, Wstęp, s. 6-7; Karavites, Evil - Freedom, s. 5; Kowalewska - Szczur, Klemens Aleksandryjski, s. 638; Naumowicz, Środowisko aleksandryjskie, s. 1079; Osborn, Clement of Alexandria, s. 14-20; M. Szarmach, Wstęp, w: Klemens Aleksandryjski, Wychowawca, s. 7.

${ }^{8}$ Por. Altaner, s. 277; Naumowicz, Wstęp, s. 10. Klemens cytuje w swoich dziełach ponad 360 pisarzy świeckich.

${ }^{9}$ Por. Karavites, Evil - Freedom, s. 4.

${ }^{10}$ P. Szczur, Wpływ starożytnej myśli greckiej na kształtowanie się koncepcji roztropności

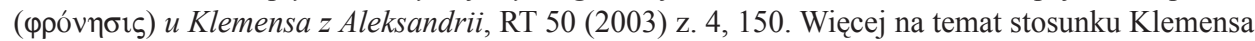
do hellenizmu i filozofii greckiej w: R.E. Witt, The Hellenism of Clement of Alexandria, CQ 25 (1931) fasc. 3/4, 195-204; J.T. Muckle, Clement of Alexandria on Philosophy as a Divine Testament for the Greeks, „Phoenix” 5 (1951) fasc. 3/4, 79-86; J.M. Szymusiak, Klasycyzm Klemensa Aleksandryjskiego, STV 9 (1971) fasc. 1, 289-302; J. Wojtczak, Stosunek Klemensa Aleksandryjskiego do filozofii wedtug Stromata, STV 9 (1971) fasc. 1, 263-288; Altaner, s. 277 i 281; W. Jaeger, Wczesne chrześcijaństwo i grecka Paideia, tłum. K. Bielawski, Bydgoszcz 2001, 77-88; Drączkowski, Klemens Aleksandryjski, EK IX 101-102; Kowalewska - Szczur, Klemens Aleksandryjski, s. 639; P. Szczur, Wiara matka miłości chrześcijańskiej wedtug Klemensa Aleksandryjskiego, VV 5 (2004) 129; tenże, Vetera et nova w koncepcji aretologii Klemensa Aleksandryjskiego, RT 53 (2006) z. 4, passim; S. Łucarz, Grób czy światynia? Problematyka cielesności w antropologii Klemensa Aleksandryjskiego, Kraków 2007, 5-10; A. Heszen, „Paideia” Klemensa Aleksandryjskiego na przykładzie jego „Hymnu do Chrystusa Zbawiciela”, „Symbolae Philologorum Posnaniensium Graecae et
} 
Bez watpienia jednak to Pismo Święte odgrywało w jego nauce pierwszoplanową rolę ${ }^{11}$.

Najbardziej twórczy okres życia Klemensa przypadł na czas jego pobytu w Aleksandrii; stąd też zyskał on swój przydomek. Z bogatej spuścizny literackiej Scholarchy do dziś w całości zachowały się tylko trzy pisma oraz jedna homilia ${ }^{12}$. Dzieło zatytułowane Protreptyk albo Zachęta Greków adresowane jest do pogan i stanowi surową krytykę ich wierzeń i poglądów oraz wezwanie do przyjęcia chrześcijaństwa. Kontynuacją Zachęty jest Wychowawca, skierowany do chrześcijan, mający na celu przyjście im z pomocą $\mathrm{w}$ umocnieniu i pogłębieniu ich wiary. Najobszerniejszym i największym utworem, jaki wyszedł spod ręki Aleksandryjczyka, są Kobierce. Jest to zbiór zapisków poruszających różnorakie kwestie dotyczące filozofii nowej wiary. Jak zauważa Józef Naumowicz, „Chyba w żadnym innym utworze nie powiedziano tyle o paralelach bądź pokrewieństwie między chrześcijaństwem i kulturą grecką"13. Dysponujemy również homilią pt. Który człowiek bogaty może być zbawiony?, stanowiącą komentarz do fragmentu Ewangelii według św. Marka (Mk 10, 17-31) i omawiającą problem bogactwa w życiu człowieka. Inne pisma Klemensa znamy tylko z fragmentów. Wszystkie te utwory dowodzą wszechstronnych zainteresowań oraz olbrzymiej erudycji ich autora ${ }^{14}$.

Wychowawca, z którego pochodzi cytowany na początku naszego tekstu fragment mówiący o chlebie, powstał po Protreptyk $u^{15}$ i składa się $\mathrm{z}$ trzech

Latinae” 19 (2009) 121-122 i 133; M. Czarnuch, Clement of Alexandria's Attitude towards the Greek Philosophy, „Scripta Classica” 10 (2013) 141-146.

${ }^{11}$ Por. np. J. Słomka, Ciało i krew Jezusa jako pokarm. J 6,48-58 w interpretacji Klemensa Aleksandryjskiego, SSHT 37 (2004) fasc. 2, 131; J. Zieliński, Filozofia Logosu jako alegoretyczna hermeneutyka. Klemens Aleksandryjski, „Theologica Wratislaviensia” 1 (2006) 99-107; M. Szarmach, O pewnej dygresji u Klemensa Aleksandryjskiego. (Czemu poświęca się czas: Paedagogus III 26-30), VoxP 28 (2008) t. 52/2, 1065; D. Zagórski, Dzieje Apostolskie w wykładzie „Kobierców” Klemensa Aleksandryjskiego, „Biblica et Patristica Thoruniensia” 1 (2008) 263-278.

${ }^{12}$ Por. np. Altaner, s. 278-281; Naumowicz, Wstęp, s. 7-10; Campenhausen, Ojcowie Kościoła, s. 3-34; Karavites, Evil - Freedom, s. 5-8; Vidal Manzanares, Klemens Aleksandryjski, s. 116-117; Wojtczak, Klemens Aleksandrinos, s. 289; Drączkowski, Klemens Aleksandryjski, EK IX 99-100; Kowalewska - Szczur, Klemens Aleksandryjski, s. 638-639; Naumowicz, Środowisko aleksandryjskie, s. 1080-1082; Osborn, Clement of Alexandria, s. 5-15; Szarmach, Wstę, s. 8-9.

${ }^{13}$ Naumowicz, Wstę, s. 8.

${ }^{14}$ Por. tenże, Środowisko aleksandryjskie, s. 1081. F. Drączkowski (Eklezjologia Klemensa Aleksandryjskiego, w: Kościót starożytny - Królestwo Chrystusa i instytucja, red. F. Drączkowski i in., Lublin 2010, 51) podkreśla jednak, że Klemens zaliczany jest do najtrudniejszych pisarzy w całej literaturze patrystycznej, ponieważ okoliczności w jakich tworzył - czasy prześladowań i obowiązująca w nich zasada misteryjności wykładu - sprawiły, że z założenia unikał jasności i przejrzystości wykładu. O stylu pisarskim Klemensa również w: Jaeger, Wczesne chrześcijaństwo, s. 75-76; H. Chadwick, Myśl wczesnochrześcijańska a tradycja klasyczna, thum. P. Siejkowski, Poznań 2000, 44; T. Klibengajtis, „Nasiona prawdy” pogan. Poezja jako locus theologicus wedlug Klemensa z Aleksandrii, CT 73 (2003) fasc. 3, passim.

${ }^{15} \mathrm{O}$ teoriach dotyczących wzajemnego związku, w jakim pozostają ze sobą trzy główne pisma 
ksiag. Zawarte $\mathrm{w}$ tym utworze pouczenia przeznaczone są dla nawróconych pogan, zaś tytułowym wychowawcą jest sam Chrystus. Pierwszą część utworu stanowią teoretyczne rozważania o chrześcijańskiej etyce, dwie następne podają szereg szczegółowych zasad odnoszących się do codziennego postępowania właściwego chrześcijaninowi. Znajdujemy tutaj m.in. uwagi na temat odpowiedniego zachowania się przy stole ${ }^{16}$, w łaźni i gimnazjonie, rady w kwestii pielęgnacji ciała ${ }^{17}$, stroju i urządzenia domu, nauczanie dotyczące form życia społecznego ${ }^{18}$ i małżeńskiego oraz etyki seksualnej ${ }^{19}$. Wychowaw$c a$ uchodzi wobec tego za przeznaczony dla chrześcijan traktat praktycznej nauki moralnej ${ }^{20}$. Jest to również cenne źródło historyczne pozwalające poznać luksusy życia w tak zamożnym i wielkim mieście, jakim była Aleksandria na przełomie II i III wieku.

W tym miejscu należy podkreślić, że Klemens nie wymaga od odbiorców swojej nauki przestrzegania surowej ascezy oraz porzucenia wszelkich radości i przyjemności. Zależy mu jedynie na tym, by utrzymywali właściwą miarę i zadowalali się prostą egzystencją ${ }^{21}$. Głosi to w myśl zasady złotego środka, którą zaleca stosować w każdym aspekcie ludzkiego życia ${ }^{22}$. Wyraźnie widoczne jest tutaj odniesienie do greckiego ideału $\mu \varepsilon \sigma o ́ \tau \eta \varsigma^{23}$. Wobec powyższego, nasz autor, najprawdopodobniej sam będąc osobą zamożną ${ }^{24}$, nie potępia m.in. bogactwa, które samo w sobie jest dla niego moralnie obojętne $\left(\alpha ̉ \delta ı \alpha ́(\varphi \rho \rho)\right.$ - ani dobre, ani złe ${ }^{25}$. Nie pozwala się go wyrzekać, wierząc, że

Aleksandryjczyka zob. W. Wagner, Another Look at the Literary Problem in Clement of Alexandria's Major Writings, ChH 37 (1968) fasc. 3, 251-260.

${ }^{16}$ Por. B. Leyerle, Clement of Alexandria on the Importance of Table Etiquette, JECS 3 (1995) fasc. 2, 123-141.

${ }^{17}$ Por. D. Zagórski, Troska o ciało w „Pedagogu” Klemensa Aleksandryjskiego, PChr 2 (2005) 29-37.

${ }^{18} \mathrm{~Np}$. używania odpowiedniego słownictwa, por. M. Szarmach, Klemens Aleksandryjski O stowach nieprzyzwoitych, ,Terminus” 12 (2010) fasc. 1, 221-224.

${ }^{19}$ Por. T. Siorek, Elementy etyki seksualnej w „Pedagogu” Klemensa Aleksandryjskiego, TPatr 5 (2008) 169-190.

${ }^{20}$ Por. Heszen, ,,Paideia” Klemensa Aleksandryjskiego, s. 123.

${ }^{21}$ Por. Altaner, s. 279; Naumowicz, Środowisko aleksandryjskie, s. 1080.

${ }^{22}$ Por. Clemens Alexandrinus, Paedagogus II 1, 16.

${ }^{23}$ Zdaniem D. Zagórskiego (,,Miarq wszystkich rzeczy jest Bóg”. Platońska zasada w interpretacji Klemensa Aleksandryjskiego, RT 50 (2003) z. 4, 245-255), Aleksandryjczyk rozumie ten ideał jako zachowanie w każdym aspekcie ludzkiego życia umiaru i powściągliwości zgodnej z roz-

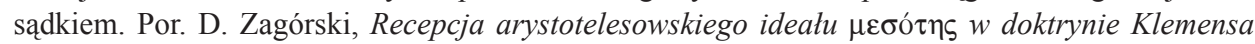

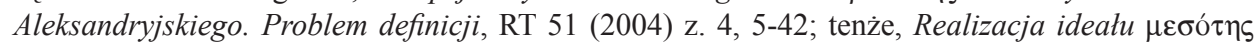
$w$ życiu matżeńskim i rodzinnym wedtug Klemensa Aleksandryjskiego, RT 52 (2005) z. 4, 5-24;

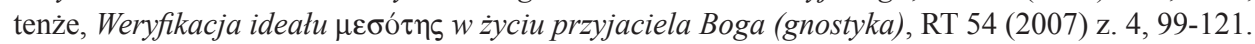

${ }^{24}$ Por. J. Pałucki, Dobre bogactwo, Lublin 1992, 5; P. Szczur, Chrześcijanie wobec bogactwa w nauczaniu Klemensa Aleksandryjskiego, „Archiwa, Biblioteki i Muzea Kościelne” 98 (2012) 395.

${ }^{25}$ Bliskie podobieństwo myśli i języka Klemensa do nauki stoików dotyczącej interpretacji ter- 
odpowiednio użyte może przynieść pożytek tym, którzy się nim posługują ${ }^{26}$. Również pożywienie zalicza on do kategorii rzeczy obojętnych ${ }^{27}$. Mówiąc o skromnym sposobie odżywiania się, odrzuca dwa ekstrema, jakimi są posty fizyczne i jedzenie nadmiernie wyszukane

,[...] nie należy odżywiać się smakołykami i pokarmami łakomczuchów, tak też i przeciwnie właściwe jest unikanie diety przesadnej. Przestrzegajmy tej, mieszczącej się między skrajnościami, rozsądnej, odpowiedniej i wolnej z jednej strony od zbytku, z drugiej od nadmiernych ograniczeńn" ${ }^{28}$.

Potępieniu luksusowej żywności ${ }^{29}$ i nadmiernego spożywania alkoholu ${ }^{30}$ poświęca on w Wychowawcy wiele miejsca. Zaleca natomiast dbanie o ciało, ponieważ im ono jest zdrowsze, tym zdrowsza jest dusza, to z kolei pozwala na stworzenie lepszej wspólnoty chrześcijańskiej ${ }^{31}$.

2. Życie i osiągnięcia Galena. Galen, najwybitniejszy grecki lekarz epoki przełomu II i III w., urodził się w roku $129^{32}$ w małoazjatyckim Pergamo-

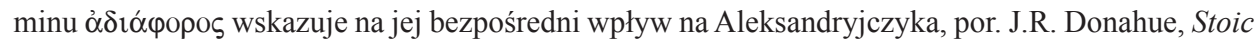
Indifferents and Christian Indifference in Clement of Alexandria, „Traditio” 19 (1963) 438-446.

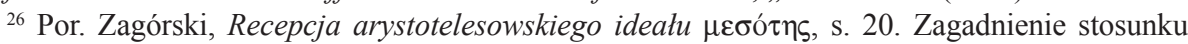
chrześcijan do dóbr materialnych Klemens poruszył przede wszystkim w homilii Który człowiek bogaty może być zbawiony? oraz w kilku fragmentach Wychowawcy. Jego poglądy w tym względzie są szeroko dyskutowane w nauce, zob. np. Pałucki, Dobre bogactwo, passim; Naumowicz, Wstęp, s. 5-32; J. Jundziłł, Czy człowiek bogaty może być zbawiony? Bogactwo i ubóstwo w świetle myśli patrystycznej, w: Patrystyczne dziedzictwo społecznej nauki Kościoła. VIII Bydgoskie Dni Społeczne (14-18 III 1994), red. T. Makowski, Gniezno 1996, 36-37; J. Ossowski, Czy bogacz może być zbawiony? Uwagi na marginesie traktatu Klemensa z Aleksandrii, „Pieniądze i Więź” (1998) fasc. 1, 21-24; J. Pałucki, Chrześcijanie wobec dóbr materialnych. Stanowisko Klemensa Aleksandryjskiego, „Cywilizacja" (2007) nr 20, 178-190; R.M. Pancerz, Chrześcijanin a dobra materialne w refleksji Szkoty Aleksandryjskiej. Od Klemensa do Dydyma, VoxP 32 (2012) t. 57, 483-493; Szczur, Chrześcijanie wobec bogactwa, s. 393-406; B. Czyżewski, ,Idź, sprzedaj, co posiadasz, i rozdaj ubogim, a będziesz miat skarb w niebie" (Mt 19,21) w egzegezie Ojców Kościoła, TPatr 10 (2013) 33; P. Szczur, Czy człowiek bogaty może być zbawiony? Stanowisko Klemensa Aleksandryjskiego, TPatr 10 (2013) 4356. Zasady postulowane w tym temacie przez Aleksandryjczyka odbiegały od tych, które chrześcijaństwo promowało od początków swojego istnienia (por. M. Karczewski, ,, Wszystko mieli wspólne” (Dz 2,44b). Pierwsi chrześcijanie wobec dóbr materialnych, „Forum Teologiczne” 7 (2006) 15-28); różniły się także od poglądów wyrażanych przez zdecydowaną większość Ojców Kościoła (zob. Czyżewski, ,Idź, sprzedaj...”, s. 41-42; Szczur, Czy czlowiek bogaty, s. 43).

${ }^{27}$ Por. Donahue, Stoic Indifferents, s. 440.

${ }^{28}$ Clemens Alexandrinus, Paedagogus III 10, 51, ed. C. Mondésert - C. Matray - H.I. Marrou, SCh 158, Paris 1970, 110-112, thum. Szarmach, s. 198. Por. Zagórski, Weryfikacja ideału, s. 104-105.

${ }^{29}$ Por. Clemens Alexandrinus, Paedagogus II 1, 1-18.

${ }^{30}$ Por. tamże II 1, 19-34.

${ }^{31}$ Por. M. Desjardins, Clement's Bound Body, w: Mapping Gender in Ancient Religious Discourses, ed. T. Penner - C. Vander Stichele, Leiden - Biggleswade 2006, 414-415.

${ }^{32}$ Odnośnie do ustaleń dotyczących daty narodzin Galena zob. V. Nutton, The Chronology of Galen's Early Career, CQ 23 (1973) 159-161. Więcej na jego temat m.in. w: G. Sarton, Galen of 
nie. Mnogość informacji dotyczących swojego życia zawarł on we własnych pismach, wprowadzając je tam - zdaniem Vivian Nutton - po to, by uatrakcyjnić suchą i pozbawioną kolorytu narrację, jak i po to, by pokazać, iż cnotą i zdolnościami góruje nad innymi lekarzami ${ }^{33}$. Dowiadujemy się od niego, że to za sprawą swojego ojca, zamożnego architekta, rozpoczął studia medyczne. Po jego śmierci, w 148 lub 149 r., spędził kilka lat na nauce u różnych mistrzów, udając się w ich poszukiwaniu do Smyrny, Koryntu i Aleksandrii ${ }^{34}$. W tej ostatniej przebywał przynajmniej cztery lata ${ }^{35}$, ale poskapił nam szczegółów dotyczących pobytu tutaj ${ }^{36}$. Wróciwszy do rodzinnego miasta, zapewne w roku $157^{37}$, objął obowiązki medyka w szkole gladiatorów. Dzięki tej praktyce pogłębił swoją wiedzę na temat anatomii człowieka; ponadto eksperymentował z doborem właściwej diety, która miała zapewniać jego podopiecznym zdrowie i siłę 38 . W 162 r. Galen po raz pierwszy przybył do Rzymu, gdzie zdobył reputację zdolnego medyka i nawiązał znajomości z wpływowymi ludźmi. Po czterech latach powrócił do Pergamonu, ale już w 168 r. cesarz Marek Aureliusz wezwał go z powrotem na Zachód. Z tego, co wiemy, aż do śmierci pozostał w Rzymie, gdzie pełnił funkcję cesarskiego lekarza na dworze kolejnych władców - Marka Aureliusza, Kommodusa i Septymiusza

Pergamon, Lawrence 1954; P. Prioreschi, A History of Medicine, vol. 3: Roman Medicine, Omaha 1998, 315-319; M. Grant, Introduction, w: Galen, On Food and Diet, transl. M. Grant, London 2000, 1-13; Nutton, Ancient Medicine, s. 216-229; taż, Galen of Pergamum, w: Brill's New Pauly. Encyclopaedia of the Ancient World, vol. 5, ed. H. Cancik - H. Schneider, Leiden - Boston 2004, 654-661; M. Kokoszko, Ryby i ich znaczenie w życiu codziennym ludzi późnego antyku i wczesnego Bizancjum (III-VII w.), Łódź 2005, 12-13; R.J. Hankinson, Galen of Pergamon, w: The Encyclopedia of Ancient Natural Scientists, s. 335-339; tenże, The Man and His Work, w: The Cambridge Companion to Galen, ed. R.J. Hankinson, Cambridge - New York 2008, 1-33.

${ }^{33}$ Por. V. Nutton, Galen and Medical Autobiography, „Proceedings of the Cambridge Philosophical Society" 18 (1972) 50-62. Źródła historyczne pochodzące z czasów, w których żył Galen, nie zawierają informacji dotyczących jego życia, zob. A. Bednarczyk, Galen. Gtówne kategorie systemu filozoficzno-lekarskiego, Warszawa 1995, 8-9. Na marginesie warto podkreślić, że spuścizna piśmiennicza naszego lekarza pozwala dobrze poznać również historię społeczną jego epoki, por. L. Thorndike, Galen. The Man and His Times, „The Scientific Monthly” 14 (1922) fasc. 1, 83-93.

${ }^{34}$ Chronologia wydarzeń z wczesnego okresu medycznej kariery Galena ustalona w Nutton, The Chronology of Galen's, s. 158-171. Patrz też Prioreschi, A History of Medicine, s. 317-321.

${ }^{35}$ Por. V. Nutton, Galen and Egypt, w: Galen und das hellenistische Erbe. Verhandlungen des IV. Internationalen Galen-Symposiums veranstaltet vom Institut für Geschichte der Medizin (Charité) der Humboldt-Universität zu Berlin, 18.-20. September 1989, Hrsg. J. Kollesch - D. Nickel, Stuttgart 1993, 26. Zob. też Sarton, Galen of Pergamon, s. 18 (uważa że było to co najmniej pięć lat) i J. Scarborough, Galen and the Gladiators, „Episteme” 5 (1971) 106 (Galen miał spędzić w Egipcie ok. ośmiu lat).

${ }^{36}$ Galen mało, a jeśli już to krytycznie, wypowiada się na temat tego, jak wyglądała jego edukacja w Aleksandrii. O powodach, dla których tak postępuje, zob. Nutton, Galen and Egypt, s. 11-31.

${ }^{37}$ Por. tamże, s. 11.

${ }^{38}$ Por. Scarborough, Galen and the Gladiators, s. 98-111. 
Sewera. Zmarł mniej więcej w tym samym czasie, co Klemens Aleksandryjski, a więc w okolicach roku $215^{39}$.

Dorobek piśmienniczy Galena jest olbrzymi ${ }^{40}$. Mimo że zachowało się jedynie ok. dwóch trzecich jego dzieł, to i tak wydane w oryginale, w latach 1821-1833, przez Karla Gottloba Kühna liczą ponad sto dwadzieścia tytułów i mieszczą się w dwudziestu dwóch wolumenach. Zbudowany przez tego starożytnego lekarza system medycyny był wzorem naukowości i ścisłości przez wiele wieków ${ }^{41}$. Po raz pierwszy, w poł. IV w., niektóre z dzieł Pergamończyka zacytował i omówił Orybazjusz, lekarz bizantyński ${ }^{42}$. Od tego momentu zaczęto się na nie coraz częściej powoływać, przytaczać je i przepisywać. Dużą rolę w przywróceniu Galena medycynie odegrali też lekarze arabscy ${ }^{43}$.

Galenowy korpus, w skład którego wchodzą m.in. pisma dotyczące różnego rodzaju pokarmów ${ }^{44}$, stanowi bogate źródło informacji dla historyków zajmujących się badaniem antycznej kuchni, zawiera bowiem nie tylko dane na temat poszczególnych produktów spożywczych, ale i przepisy kulinarne ${ }^{45}$. Wynika to $\mathrm{z}$ faktu, iż w starożytności dietetyka, obok chirurgii i farmakologii, była jedną z trzech głównych gałęzi medycyny. Stosując się do jej zaleceń, nie tylko prowadzono leczenie, ale i starano się zapobiegać chorobom ${ }^{46}$. Zatem, zdaniem

${ }^{39}$ Zgodnie z dawną tradycją, datą śmierci Galena miał być rok 199, jednak V. Nutton (Galen in the Eyes of His Contemporaries, „Bulletin of the History of Medicine” 58 (1984) fasc. 3, 323-324), odwołując się do źródeł arabskich, przekonująco argumentuje przesunięcie jej o ok. dziesięć lub nawet więcej lat później.

${ }^{40}$ Por. m.in. Sarton, Galen of Pergamon, s. 25-29; Prioreschi, A History of Medicine, s. 319330; Hankinson, Galen of Pergamon, s. 335.

${ }^{41}$ Por. J. Świderek, Metody medycyny naukowej w ujęciu Galena, „Zagadnienia Naukoznawstwa" 43 (2007) fasc. 2, 248.

${ }^{42}$ Orybazjusz był przybocznym lekarzem cesarza Juliana Apostaty. W latach 361-363 sporządził wyciagi z prac wybitnych medyków (Collectiones medicae). Ślepo przejmował wszystkie poglądy Galena, więcej np. w: J. Scarborough, Oreibasios of Pergamon, w: The Encyclopedia of Ancient Natural Scientists, s. 595-596; K. Jagusiak - M. Kokoszko, Życie i kariera Orybazjusza $w$ świetle relacji źródlowych, „Przegląd Nauk Historycznych” 10 (2011) fasc. 1, 5-21; ciż, Pisma Orybazjusza jako źródto informacji o pożywieniu ludzi w późnym Cesarstwie Rzymskim, VoxP 33 (2013) t. 59, 339-357.

${ }^{43}$ Por. Bednarczyk, Galen. Główne kategorie, s. 9.

${ }^{44}$ Cenne jest zwłaszcza pismo powstałe ok. 180 r. i znane pod łacińskim tytułem De alimentorum facultatibus (w niniejszym opracowaniu posłużono się wydaniem: Claudii Galeni Opera omnia, ed. D.C.G. Kühn, vol. 6, Lipsiae 1823) por. J. Wilkins, Foreword, w: Galen, On the properties of foodstuffs (De alimentorum facultatibus), transl. O. Powell, Cambridge 2003, IX-XXI.

${ }^{45}$ Por. A. Dalby, Food in the Ancient World from A to Z, London - New York 2003, 154-155. Szerzej o bogactwie informacji na temat antycznej i wczesnobizantyńskiej kuchni zawartych w ówczesnych traktatach medycznych w: M. Kokoszko - K. Jagusiak - Z. Rzeźnicka, Wstęp. Wiedza o pokarmach w źródłach medycznych. Dietetyka, farmakologia i sztuka kulinarna, w: ciż, Dietetyka i sztuka kulinarna antyku i wczesnego Bizancjum (II-VII w.), cz. 1: Zboża i produkty zbożowe w źródtach medycznych antyku i wczesnego Bizancjum, Łódź 2014, 5-26.

${ }^{46}$ Por. I. Mazzini, Diet and Medicine in the Ancient World, w: Food. A Culinary History from 
Galena, zdrowie można zachować lub odzyskać, sięgając po odpowiedni pokarm, stracić zaś, posilając się niewłaściwym lub nieprawidłowo przyrządzonym pożywieniem. Co więcej, w opinii naszego medyka, własności poszczególnych składników diety łączą się z czterema humorami $(\chi \vee \mu o i ́)^{47}$, które w organizmie ludzkim muszą występować we właściwych proporcjach ${ }^{48}$. Materiał potrzebny do omówienia szerokiego wachlarza różnego rodzaju produktów spożywczych lekarz z Pergamonu zebrał w oparciu o lekturę pism medycznych swoich poprzedników ${ }^{49}$ oraz własne obserwacje poczynione w największych miastach cesarstwa i w miejscach, które odwiedzał w trakcie licznych podróży odbywanych $\mathrm{w}$ celu odkrycia nowych medykamentó $\mathrm{w}^{50}$. Ważną rolę $\mathrm{w}$ jego nauce odgrywają zboża, a także pokarmy uzyskiwane z nich na skutek różnych zabiegów kulinarnych, w tym interesujący nas chleb ${ }^{51}$. Pamiętać jednak należy, iż dietetyka definiowana w sposób, w jaki czynił to Galen, mogła przyjść

Antiquity to the Present, under the direction of J.-L. Flandrin - M. Montanari; Eng. ed. A. Sonnenfeld, New York - Chichester 1999, 141-152; Grant, Introduction, s. 6-7. Pamiętać jednak należy, że greckie pojęcie $\delta i ́ \alpha \imath \tau \alpha$ miało wówczas znacznie szersze znaczenie niż obecnie i odnosiło się nie tylko do pokarmu spożywanego przez człowieka, ale do całokształtu trybu jego życia, por. M. Kokoszko - K. Jagusiak - Z. Rzeźnicka, Wstęp. Dietetyka, farmakologia i sztuka kulinarna w źródtach medycznych, w: Dietetyka i sztuka kulinarna antyku i wczesnego Bizancjum (II-VII w.), cz. 2: Pokarm dla ciała i ducha, red. M. Kokoszko, Łódź 2014, 55.

${ }^{47}$ Owymi czterema humorami, czyli sokami organicznymi, były: krew, żółć, czarna żółć i flegma. Zdrowie człowieka miało zależeć zarówno od właściwej proporcji ich zmieszania, jak i zachowania ich cech charakterystycznych (tj. wilgoci, suchości, ciepła i zimna) w stanie pierwotnym. Zob. N. Arikha, Passions and Tempers. A History of the Humours, New York 2007, 3-47; J. Bos, The Rise and Decline of Character. Humoral Psychology in Ancient and Early Modern Medical Theory, „History of the Human Sciences” 22 (2009) fasc. 3, 29-50; J. Jouanna, La théorie des quatre humeurs et des quatre tempéraments dans la tradition latine (Vindicien, Pseudo-Soranos) et une source grecque retrouvée, REG 118 (2005) fasc. 1, 138-167; M. Kokoszko - Z. Rzeźnicka, Dietetyka w „De re coquinaria”, „Przegląd Nauk Historycznych” 10 (2011) fasc. 2, 8-10.

${ }^{48}$ Szczegóły dotyczące Galenowej dietetyki m.in. w: Grant, Introduction, s. 8-10; Nutton, Ancient Medicine, s. 240-241; S. Vogt, Drugs and Pharmacology, w: The Cambridge Companion to Galen, 306-307.

${ }^{49}$ Galen pozostawał szczególnie pod olbrzymim wpływem doktryn sformułowanych w V-IV w. prz. Chr. przez Hipokratesa (o Hipokratesie zob. J. Jouanna, Hippokratēs of Khos, w: The Encyclopedia of Ancient Natural Scientists, s. 401-405; Kokoszko - Jagusiak - Rzeźnicka, Dietetyka i sztuka kulinarna, cz. 1, s. 579). M. Grant (Introduction, s. 5-6) uważa, iż Pergamończyk idealizował swojego poprzednika do tego stopnia, że niekiedy traktował go niczym boga. Zob. też: Bednarczyk, Galen. Główne kategorie, passim; Kokoszko, Ryby i ich znaczenie, s. 12; Kokoszko - Jagusiak Rzeźnicka, Wstep. Dietetyka, s. 58-59.

${ }^{50}$ Por. V. Nutton, Galen and the Traveler's Fare, w: Food in Antiquity, ed. J. Wilkins - D. Harvey - M. Dobson, Exeter 1999, 363.

${ }^{51}$ Miejsce zbóż oraz uzyskiwanych z nich produktów w medycynie czasów antycznych i wczesnobizantyńskich, w tym także w nauce Galena, szczegółowo omówione zostało w: Kokoszko Jagusiak - Rzeźnicka, Dietetyka i sztuka kulinarna, cz. 1, passim oraz ciż, Cereals of Antiquity and Early Byzantine Times. Wheat and Barley in Medical Sources (Second to Seventh Centuries AD), transl. K. Wodarczyk - M. Zakrzewski - M. Zytka, Łódź - Kraków 2014, passim. 
z pomocą jedynie ludziom, których stać było na jedzenie służące ich zdrowiu. Z pewnością z jej ustaleń korzystali pacjenci Pergamończyka, którzy w zdecydowanej większości należeli do elity ówczesnego społeczeństwa rzymskiego ${ }^{52}$. To do takich osób medyk kierował swoje zalecenia ${ }^{53}$, podobnie jak Klemens Aleksandryjski cytowaną uwagę o zbyt wytwornym pieczywie.

3. Klemens Aleksandryjski a medycyna. Jan Maria Szymusiak zauważa, że jedyną nauką, której przejawy obecne są w Wychowawcy, jest medycyna. Znajdujemy tutaj teorie Hipokratesa w formie, jaką mają one u Galena ${ }^{54}$. Klemens może pochwalić się specjalistyczną wiedzą m.in. na temat układu rozrodczego kobiety ${ }^{55}$ i powstania ludzkiego embrionu ${ }^{56}$; wie, że regularny puls świadczy o dobrym stanie zdrowia ${ }^{57}$. Wypowiada się także w kwestiach związanych $z$ dietetyką. Wylicza szkodzące organizmowi ludzkiemu oraz lecznicze właściwości kwiatów ${ }^{58}$ i odwołuje się do teorii czterech humorów ${ }^{59}$, o których wiele nauczał Galen ${ }^{60}$. Aleksandryjczyk stwierdza wprost, że dzięki należytej diecie człowiek jest zdrowy ${ }^{61}$. Choć Klemensowi zdarza się imiennie przywoływać antycznych medyków ${ }^{62}$, nie natrafiamy u niego na bezpośrednią wzmiankę o Pergamończyku. Jest mało prawdopodobne, by obydwaj kiedykolwiek się spotkali, skoro jednak nasz lekarz był znany i ceniony przez mu współczesnych ${ }^{63}$, również w Egipcie ${ }^{64}$, to Scholarcha mógł czytać jego pisma. We współczesnej nauce pojawiła się nawet hipoteza mówiąca o zainspirowaniu się przez Klemensa jedną z zaginionych prac Galena poświęconych zagadnieniom z dziedziny logiki ${ }^{65}$.

${ }^{52}$ Por. H.F.J. Horstmanshoff, Galen and His Patients, w: Ancient Medicine in its Socio-Cultural Context. Papers Read at the Congress Held at Leiden University, 13-15 April 1992, vol. 1, ed. Ph.J. van der Eijk - H.F.J. Horstmanshoff - P.H. Schrijvers, Amsterdam - Atlanta 1995, 88-92.

${ }^{53}$ Por. K. Kokoszko - K. Jagusiak, Pszenice antyku i Bizancjum, w: Kokoszko - Jagusiak Rzeźnicka, Dietetyka i sztuka kulinarna, cz. 1, s. 52-53; ciż, Wheats of Antiquity and Byzantium, w: Kokoszko - Jagusiak - Rzeźnicka, Cereals of Antiquity and Early Byzantine Times, s. 55.

${ }^{54}$ Por. Szymusiak, Klasycyzm Klemensa, s. 293.

${ }^{55}$ Por. Clemens Alexandrinus, Paedagogus II 10, 92.

${ }^{56}$ Por. tamże I 6, 48.

${ }^{57}$ Por. tamże III 11, 55.

${ }^{58}$ Por. tamże II 8, 71 i 76.

${ }^{59}$ Por. tamże III 11, 64-65; I 11, 96.

${ }^{60}$ Zob. np. Arikha, Passions and Tempers, s. 26-39.

${ }^{61}$ Por. Clemens Alexandrinus, Paedagogus III 11, 64. Zob. T.M. Shaw, Vegetarianism, Heresy, and Asceticism in Late Ancient Christianity, w: Eating and Believing. Interdisciplinary Perspectives on Vegetarianism and Theology, ed. D. Grumett - R. Muers, London 2008, 78-80.

${ }^{62} \mathrm{~Np}$. żyjącego w V w. prz. Chr. Diogenesa z Apolonii, por. Clemens Alexandrinus, Paedagogus I 6, 48 (o Diogenesie zob. D.W. Graham, Diogenēs of Apollōnia, w: The Encyclopedia of Ancient Natural Scientists, s. 252).

${ }^{63}$ Por. Nutton, Galen in the Eyes, s. 315-324.

${ }^{64}$ Por. tamże, s. 317-318.

${ }^{65}$ Por. M. Havrda, Galenus Christianus? The Doctrine of Demonstration in Stromata VIII and the Question of its Source, VigCh 65 (2011) 343-375. 
4. Pszenica w epoce starożytnej. Podstawę diety społeczeństw antycznych zamieszkujących obszar basenu Morza Śródziemnego stanowiły produkty zbożowe ${ }^{66}$. Spośród zbóż, jakie wówczas uprawiano, największą popularnością cieszył się jęczmień i pszenica ${ }^{67}$, zdecydowanie jednak preferowano tę drugą ${ }^{68}$. Jej wyższość głosili w swoich pismach greccy medycy, dramaturdzy i filozofowie ${ }^{69}$.

Dziś znanych jest ok. 30 tys. odmian pszenicy ${ }^{70}$, którymi żywi się 35\% populacji całego globu ${ }^{71}$. W czasach starożytnych na interesujących nas terenach najważniejszymi były: niewymagająca łuskania pszenica zwyczajna (Triticum aestivum L.), pszenica twarda (Triticum durum Desf.) i pszenica karłowata (Triticum compactum Host) oraz posiadające łuskę pszenica płaskurka

${ }^{66}$ Por. L. Darmezin, L'approvisionnement en blé des cités grecques à l'époque hellénistique, w: Rites et rythmes agraires. Séminaire de recherche sous la direction de Marie-Claire Cauvin, Lyon 1991, 113; G. Reger, The Public Purchase of Grain on Independent Delos, „Classical Antiquity” 12 (1993) fasc. 2, 300; P. Garnsey, Food and Society in Classical Antiquity, Cambridge 1999, 17-19; N. Purcell, The Way We Used to Eat. Diet, Community, and History at Rome, „The American Journal of Philology" 124 (2003) fasc. 3, 332; C.K. Kaufman, Cooking in Ancient Civilizations, Westport 2006, XXXVII; M. Mazoye - L. Roudart, A History of World Agriculture. From the Neolithic Age to Current Crisis, trans. J.H. Membrez, London - Sterling 2006, 160; V. Grimm, The Good Things that Lay at Hand. Tastes of Ancient Greece and Rome, w: Food. The History of Taste, ed. P. Freedman, Berkeley 2007, 68 i 93; M. Kokoszko, Smaki Konstantynopola, w: Konstantynopol - Nowy Rzym. Miasto i ludzie w okresie wczesnobizantyńskim, red. M.J. Leszka - T. Wolińska, Warszawa 2011, 474; G. Willcox, The Beginnings of Cereal Cultivation and Domestication in Southwest Asia, w: A Companion to the Archaeology of the Ancient Near East, vol. 1, ed. D.T. Potts, Oxford 2012, 172-173; D.E. Neel - J.A. Pugh, Jedzenie i uczty Jezusa. Kulinarny świat Palestyny pierwszego wieku, thum. M. Król, Kraków 2014, 20 i 35.

${ }^{67}$ Por. E.Ch. Semple, Ancient Mediterranean Agriculture. Part I, „Agricultural History” 2 (1928) fasc. 2, 72 i 83; N. Jasny, Competition Among Grains in Classical Antiquity, „The American Historical Review” 47 (1942) fasc. 4, 752; L.A. Moritz, ,, Corn”, CQ 5 (1955) fasc. 3/4, 138; G.E. Rickman, The Grain Trade under the Roman Empire, „Memoirs of the American Academy in Rome" 36 (1980) 261; A. Dalby, Siren Feasts. A History of Food and Gastronomy in Greece, London 1996, 22; Garnsey, Food and Society, s. 15; J.P. Alcock, Food in the Ancient World, Westport - London 2006, 150; Kaufman, Cooking in Ancient, s. XXXVII; J.M. Wilkins - Sh. Hill, Food in the Ancient World, Malden - Oxford 2006, 17; Kokoszko, Smaki Konstantynopola, s. 474; M. Kokoszko - K. Jagusiak, Zboża Bizancjum. Kilka uwag na temat roli produktów zbożowych na podstawie źródet greckich, „Zeszyty Wiejskie” 17 (2012) 20; Neel - Pugh, Jedzenie i uczty Jezusa, s. 35.

${ }^{68}$ Por. H. Helbaek, Late Bronze Age and Byzantine Crops at Beycesultan in Anatolia, „Anatolian Studies" 11 (1961) 93-94; Rickman, The Grain Trade, s. 261; Kaufman, Cooking in Ancient, s. XXXVII; Grimm, The Good Things, s. 73; Kokoszko - Jagusiak, Pszenice antyku i Bizancjum, s. 45; ciż, Wheats of Antiquity and Byzantium, s. 47.

${ }^{69}$ Por. Jasny, Competition Among Grains, s. 751.

${ }^{70}$ Por. L. Civitello, Cuisine and Culture. A History of Food and People, Hoboken - Chichester 2008, 6 .

${ }^{71}$ Por. J. McCorriston, Wheat, w: The Cambridge World History of Food, vol. 1, ed. K.F. Kiple - K.C. Ornelas, Cambridge 2000, 157. 
(Triticum dicoccum Schrank) i pszenica samopsza (Triticum monococcum L.). Znano również pszenicę orkisz (Triticum spelta L.) ${ }^{72}$.

Badania prowadzone przez archeologów i botaników dowodzą, iż proces uprawy i udomowienia pszenicy rozpoczął się ok. 10 tys. lat temu na Bliskim Wschodzie, na obszarze zwanym Żyznym Półksiężycem ${ }^{73}$. Stąd zboże to rozprzestrzeniło się na inne tereny, docierając także na ziemie zajęte później przez Greków i Rzymian. Poszczególne jego gatunki pojawiały się tutaj stopniowo. Pszenica karłowata, blisko spokrewniona z płaskurką, zawitała na kontynent europejski przed nią lub w podobnym okresie. Najstarsze jej ślady

${ }^{72}$ Por. D. Zohary - M. Hopf, Domestication of Plants in the Old World. The Origin and Spread of Cultivated Plants in West Asia, Europe and in the Nile Valley, Oxford 1993, 18-31; McCorriston, Wheat, s. 165-168; Kokoszko, Smaki Konstantynopola, s. 474; Kokoszko - Jagusiak, Zboża Bizancjum, s. 20; ciż, Pszenice antyku i Bizancjum, s. 27-28; ciż, Wheats of Antiquity and Byzantium, s. 29-30. O zaletach uprawy gatunków z łuską i bez niej por. L.A. Moritz, Husked and "Naked" Grain, CQ 5 (1955) fasc. 3/4, 129; Garnsey, Food and Society, s. 120; Kaufman, Cooking in Ancient, s. XXXIX-XL.

${ }^{73} \mathrm{Z}$ bogatej literatury dotyczącej tego zagadnienia przywołać można: H. Field, Ancient Wheat and Barley from Kish, Mesopotamia, „American Anthropologist” 34 (1932) fasc. 2, 303-309; T.B. Jones, Ancient Mesopotamian Agriculture, „Agricultural History” 26 (1952) fasc. 2, 48; Helbaek, Late Bronze Age, s. 87; J.R. Harlan, The Origins of Cereal Agriculture in the Old World, w: Origins of Agriculture, ed. Ch.A. Reed, Hague 1977, passim; J.M.J. De Wet, Grasses and the Culture History of Man, „Annals of the Missouri Botanical Garden” 68 (1981) fasc. 1, 87-104; O. Bar-Yosef - R.H. Meadow, The Origins of Agriculture in the Near East, w: Last Hunters, First Farmers. New Perspectives on the Prehistoric Transition to Agriculture. Seminar. Papers, ed. T.D. Price A.B. Gebauer, Santa Fe 1995, 66-67; M. Nesbitt, Plants and People in Ancient Anatolia, „The Biblical Archaeologist" 58 (1995) fasc. 2, 72; B.D. Smith, The Emergence of Agriculture, New York 1995, 50-51; A. Garrard - S. Colledge - L. Martin, The Emergence of Crop Cultivation and Caprine Herding in the „Marginal Zone” of the Southern Levant, w: The Origins and Spread of Agriculture and Pastoralism in Eurasia, ed. D.R. Harris, London 1996, 204-226; D. Zohary, The Mode of Domestication of the Founder Crops of Southwest Asian Agriculture, w: The Origins and Spread, s. 142-158; O. Bar-Yosef, The Natufian Culture in the Levant, Threshold to the Origins of Agriculture, „Evolutionary Anthropology” 6 (1998) fasc. 5, 168-171; M. Nesbitt - S. Delwen, Wheat Domestication. Archaeobotanical Evidence, „Science” (1998) vol. 279, 1433; McCorriston, Wheat, passim; N.F. Miller - W. Wetterstrom, The Beginnings of Agriculture: The Ancient Near East and North Africa, w: The Cambridge World History of Food, vol. 2, ed. K.F. Kiple - K.C. Ornelas, Cambridge 2000, passim; F. Fernandez-Armesto, Near a Thousand Tables. A History of Food, New York 2002, 81 i 95; Mazoye - Roudart, A History of World Agriculture, s. 73 i 78; M. Balter, Seeking Agriculture's Ancient Roots, „Science” (2007) vol. 316, 1830-1835; L. Boulos - A.G. Fahmy, Grasses in Ancient Egypt, „Kew Bulletin” 62 (2007) fasc. 3, 508; M. Toussaint-Samat, Historia naturalna i moralna jedzenia, thum. A.B. Matusiak - M. Ochab, Warszawa 2008, 127-128; M.A. Zeder, The Origins of Agriculture in the Near East, „Current Anthropology” 52 (2011) Supplement 4, S221-S235; J.M. Diamond, Strzelby, zarazki, maszyny. Losy ludzkich społeczeństw, thum. M. Konarzewski, Warszawa 2012, passim; Willcox, The Beginnings of Cereal, passim. Należy pamiętać, że proces pełnej domestykacji roślin, w tym pszenicy, był bardzo powolny, zob. Balter, Seeking Agriculture's Ancient, s. 1830-1832 i Zeder, The Origins of Agriculture, s. S230-S231; o tym, na czym polegał i jak mógł wyglądać w: Diamond, Strzelby, zarazki, maszyny, s. 95-99. 
odnaleziono w Syrii i Turcji. W Grecji siano ją na Krecie i w Tesalii od mniej więcej 6 tys. lat prz. Chr., nie ma natomiast dowodów na jej obecność w Egipcie faraonów ${ }^{74}$. Pszenica samopsza, której ziarno charakteryzuje się złą jakością i słabo obradza, dotarła do Europy w podobnym czasie co pszenica karłowata. Jej znaczenie w gospodarce śródziemnomorskiej było stosunkowo niewielkie; nie uprawiali jej Egipcjanie, zaś Grecy, mimo że wspominają ją w źródłach klasycznych, jeszcze przed nastaniem tej epoki zrezygnowali z niej na rzecz innych gatunków. Ze względu na jej odporność na zimno - rośnie do wysokości 2000 m n.p.m. - do końca epoki żelaza siano ją na Bałkanach ${ }^{75}$. Od czasów prehistorycznych w basenie Morza Śródziemnego znano również pszenicę twardą. Poczynając od okresu klasycznego, zyskała ona tutaj pozycję jednego z głównych zbóż, choć zanim Hellenowie zaczęli ją uprawiać, sprowadzali ją z Bliskiego Wschodu ${ }^{76}$. Odmiana zwana płaskurką była głównym zbożem późnej epoki neolitycznej i epoki brąu w całym świecie śródziemnomorskim. Preferowali ją, aż do czasów rzymskich, rolnicy w Egipcie. Przez długi czas płaskurka rywalizowała $\mathrm{z}$ jęczmieniem, od którego była bardziej pożywna, ale mniej wydajna. Ostatecznie, w epoce klasycznej, musiała ustąpić popularnością pszenicy zwyczajnej, która bardziej nadawała się do wypieku chleba $\mathrm{i}$, ze względu na brak łuski, generowała niższe koszty marketingowe ${ }^{77}$. Orkisz najprawdopodobniej rozprzestrzenił się z obszaru dzisiejszego Pakistanu i przez Północną i Środkową Europę dotarł ok. piątego tysiąclecia prz. Chr. na tereny Śródziemnomorza i na Bliski Wschód. Udawał się dobrze w wilgotnym

${ }^{74}$ Por. Dalby, Siren Feasts, s. 90-91; tenże, Food in the Ancient World, s. 348; M. Nesbitt, Grains, w: The Cultural History of Plants, ed. G. Prance - M. Nesbitt, New York - London 2005, 53; Alcock, Food in the Ancient World, s. 32; Kokoszko - Jagusiak, Pszenice antyku i Bizancjum, s. 29; ciż, Wheats of Antiquity and Byzantium, s. 31.

${ }^{75}$ Por. Jasny, Competition Among Grains, s. 759; Harlan, The Origins of Cereal Agriculture, s. 360; G. Barker, Prehistoric Farming in Europe, Cambridge 1985, 65; Nesbitt, Plants and People, s. 74; Smith, The Emergence of Agriculture, s. 69-71; Dalby, Siren Feasts, s. 90; P. Halstead, The Development of Agriculture and Pastoralism in Greece. When, How, Who and What?, w: The Origins and Spread, s. 297; Dalby, Food in the Ancient World, s. 130; Nesbitt, Grains, s. 52; Toussaint-Samat, Historia naturalna, s. 133; Kokoszko - Jagusiak, Zboża Bizancjum, s. 23; ciż, Pszenice antyku $i$ Bizancjum, s. 29; ciż, Wheats of Antiquity and Byzantium, s. 31.

${ }^{76}$ Por. Jasny, Competition Among Grains, s. 762; Dalby, Siren Feasts, s. 91; tenże, Food in the Ancient World, s. 131; Nesbitt, Grains, s. 52; Alcock, Food in the Ancient World, s. 32; Kaufman, Cooking in Ancient, s. XLI; Kokoszko - Jagusiak, Pszenice antyku i Bizancjum, s. 29-30; ciż, Wheats of Antiquity and Byzantium, s. 31-32.

${ }^{77}$ Por. Jasny, Competition Among Grains, s. 760-761; Harlan, The Origins of Cereal Agriculture, s. 360; Barker, Prehistoric Farming, s. 64-65 i 67; Nesbitt, Plants and People, s. 74; Smith, The Emergence of Agriculture, s. 68-69; Dalby, Siren Feasts, s. 46 i 90-91; Garnsey, Food and Society, s. 120; Halstead, The Development of Agriculture, s. 296; Dalby, Food in the Ancient World, s. 131132; Nesbitt, Grains, s. 52; Alcock, Food in the Ancient World, s. 32; Kaufman, Cooking in Ancient, s. XL; Toussaint-Samat, Historia naturalna, s. 129 i 132; Kokoszko - Jagusiak, Zboża Bizancjum, s. 24; ciż, Pszenice antyku i Bizancjum, s. 30; ciż, Wheats of Antiquity and Byzantium, s. 32. 
klimacie, więc siano go w północnych prowincjach Imperium Romanum. Na ziemiach leżących w strefie klimatu śródziemnomorskiego w interesującym nas okresie nie odgrywał istotnej roli ekonomicznej ${ }^{78}$. Najpóźniej udomowioną odmianą uprawianą w antyku jest pszenica zwyczajna. Przypuszcza się, że wywodzi się ona z północno-zachodniego Iranu, gdzie pojawiła się w końcu drugiego tysiąclecia prz. Chr. Nadawała się do wypieku dobrze wyrośniętego chleba i z tego powodu zdeklasowała wszystkie znane w świecie grecko-rzymskim gatunki tego zboża. Lepsze plony dawała jednak w wilgotniejszym klimacie niż ten panujący w Grecji właściwej i w znacznej części Italii, wybór konsumentów jednak przeważył, więc importowano ją tutaj i sprzedawano po wysokich cenach ${ }^{79}$.

Pod greckim słowem $\pi$ vó́ kryło się ogólne określenie pszenicy ${ }^{80}$, ale

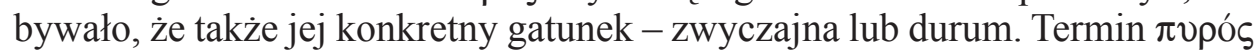

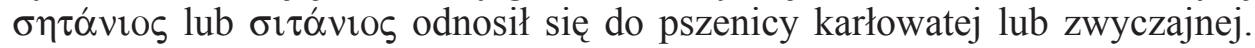
Durum znano jako $\sigma \varepsilon \mu i ́ \delta \alpha \lambda i \varsigma$ albo $\pi v \rho o ́ \varsigma ~ \sigma \varepsilon \mu t \delta \alpha \lambda i ́ \tau \varepsilon \varsigma$, zaś orkisz jako ó $\lambda v$ $\rho \alpha$, choć niekiedy ta ostatnia nazwa mogła oznaczać także płaskurkę. Słowo $\tau i ́ \varphi \eta$ określało pszenicę samopszą, ale nazywano ją również, podobnie jak

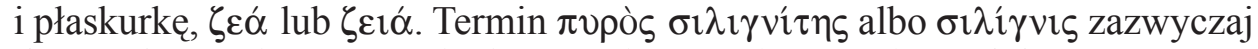

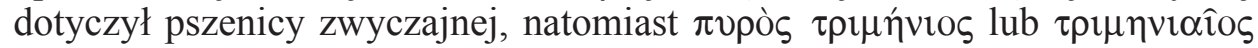
- jarej ${ }^{81}$. W języku łacińskim ogólnym pojęciem oznaczającym m.in. pszenicę było słowo frumentum. Rzymianie znali pszenicę twardą, określając ją mianem triticum, oraz zwyczajną - siligo. Najwcześniej jednak zetknęli się z płaskurką, którą nazywali far, adoreum lub semen. Przez wieki to właśnie ona była ich podstawowym pożywieniem ${ }^{82}$.

${ }^{78}$ Por. Jasny, Competition Among Grains, s. 759-760; Dalby, Food in the Ancient World, s. 309; Nesbitt, Grains, s. 52-53; Alcock, Food in the Ancient World, s. 32; Kaufman, Cooking in Ancient, s. XL; Kokoszko - Jagusiak, Pszenice antyku i Bizancjum, s. 30-31; ciż, Wheats of Antiquity and Byzantium, s. 32-33.

${ }^{79}$ Por. Jasny, Competition Among Grains, s. 772; Garnsey, Food and Society, s. 120-121; C. Perlès, The Early Neolithic in Greece. The First Farming Communities in Europe, Cambridge 2001, 62, 73 i 155; Dalby, Food in the Ancient World, s. 348; Nesbitt, Grains, s. 53; Kaufman, Cooking in Ancient, s. XLI; Toussaint-Samat, Historia naturalna, s. 132-134; Kokoszko - Jagusiak, Pszenice antyku i Bizancjum, s. 31; ciż, Wheats of Antiquity and Byzantium, s. 33.

${ }^{80}$ Szczegóły na temat greckiej terminologii gatunków pszenicy w: Kokoszko - Jagusiak, Pszenice antyku i Bizancjum, s. 243, 266-268 i 292-294; ciż, Wheats of Antiquity and Byzantium, s. 246, 268-270 i 293-294.

${ }^{81}$ Por. Dalby, Food in the Ancient World, s. 130 i 348; Kokoszko - Jagusiak, Pszenice antyku $i$ Bizancjum, s. 31-32; ciż, Wheats of Antiquity and Byzantium, s. 33-34.

${ }^{82}$ Por. N. Jasny, Wheat Prices and Milling Costs in Classical Rome, „Wheat Studies” 20 (1944) fasc. 4, 148; Alcock, Food in the Ancient World, s. 167; Kokoszko - Jagusiak, Pszenice antyku $i$ Bizancjum, s. 34; ciż, Wheats of Antiquity and Byzantium, s. 36. Zob. też Purcell, The Way We Used to Eat, s. 332-336 - na temat wykorzystywania przez Rzymian pszenicy płaskurki jako toposu literackiego. 
Pszenica jest dość wymagającą roślina, która do uprawy potrzebuje żyznej ziemi i dużo wilgoci ${ }^{83}$. Warunki te spełniały jedynie niewielkie obszary Grecji właściwej i Italii ${ }^{84}$. Wspomniane już preferencje żywieniowe konsumentów, najwyżej ceniących produkty pszenne, sprawiły, że zarówno Grecy, jak i Rzymianie zmuszeni byli do importu omawianego zboża na wielką skalę. $\mathrm{Ci}$ pierwsi sprowadzali je, od początku V w. prz. Chr., z Sycylii, Egiptu, wysp Morza Egejskiego i przede wszystkim z obszarów nad Morzem Czarnym ${ }^{85}$. Te same tereny dostarczały pszenicy Rzymianom, jednak oni, z czasem, uczynili swoim głównym spichlerzem Egipt ${ }^{86}$. W szczytowym okresie dziejów

${ }^{83}$ Por. E.Ch. Semple, Geographic Factors in the Ancient Mediterranean Grain Trade, „Annals of the Association of American Geographers" 11 (1921) 47-48; taż, Ancient Mediterranean Agriculture. Part I, s. 72-73; Jasny, Competition Among Grains, s. 753-754; Rickman, The Grain Trade, s. 261; R. Osborne, Classical Landscape with Figures. The Ancient Greek City and its Countryside, London 1987, 33; P. Garnsey, Famine and Food Supply in the Graeco-Roman World. Responses to Risk and Crisis, Cambridge 1989, 10; Reger, The Public Purchase of Grain, s. 303; Kaufman, Cooking in Ancient, s. XXXVII.

${ }^{84} \mathrm{~W}$ Grecji opady wystarczające do udanego zbioru pszenicy zdarzały się raz na 7 lat (zob. Osborne, Classical Landscape, s. 34; Garnsey, Famine and Food, s. 10). Tylko Beocja i Tesalia mogły wyprodukować taką jej ilość, by zaspokoiła potrzeby ich mieszkańców (Tesalia nawet eksportowała niewielkie nadwyżki tego zboża). Ponadto, z powodzeniem wysiewano ją na Eubei i w Macedonii. Na zachodnich obszarach Śródziemnomorza warunki jej uprawy były o wiele lepsze niż na wschodzie (za wyjątkiem Pontu i Egiptu). Na Sycylii i w części Italii - Etrurii i Kampanii - podłoże z lawy, tufu i pyłów wulkanicznych zapewniało żyzność gleby i utrzymywało jej wilgotność potrzebną zwłaszcza w okresie tuż przed żniwami. Zob. Semple, Geographic Factors, passim; taż, Ancient Mediterranean Agriculture. Part I, s. 73-74; taż, Ancient Mediterranean Agriculture. Part II. Manuring and Seed Selection, „Agricultural History” 2 (1928) fasc. 3, 148; N. Jasny, The Daily Bread of the Ancient Greeks and Romans, „Osiris” 9 (1950) 232; L. Winniczuk, Chleb u starożytnych Greków i Rzymian, „Meander” 5 (1950) 225; Rickman, The Grain Trade, s. 261; J.K. Evans, Wheat Production and Its Social Consequences in the Roman World, CQ 31 (1981) fasc. 2, 428-442; Dalby, Siren Feasts, s. 42 i 45; S.-M. Valamoti, Investigating the Prehistoric Bread of Northern Greece. The Archaeobotanical Evidence for the Neolithic and the Bronze Age, „Civilisations” 49 (2002) fasc. 1/2, 54-55 i 58-59; F. De Angelis, Going against the Grain in Sicilian Greek Economics, „Greece and Rome” 53 (2006) fasc. 1, 29-47; Grimm, The Good Things, s. 69; Toussaint-Samat, Historia naturalna, s. 137.

${ }^{85}$ Por. Semple, Geographic Factors, s. 59-71; L. Casson, Maritime Trade in Antiquity, „Archaeology" 34 (1981) fasc. 4, 38; Darmezin, L'approvisionnement en blé, s. 113-118; Mazoye - Roudart, A History of World Agriculture, s. 164 i 250; G.J. Oliver, War, Food, and Politics in Early Hellenistic Athens, Oxford - New York 2007, 37-39. Import ten miał szczególne znaczenie dla Aten w okresie klasycznym, zob. Garnsey, Famine and Food, s. 89-106, spec. 105-106; M. Whitby, The Grain Trade of Athens in the Fourth Century BC, w: Trade, Traders, and the Ancient City, ed. H. Parkins Ch. Smith, London - New York 1998, 99-124. Praktycznie jednak niemożliwe jest ustalenie, w jakim stopniu były one od niego zależne, por. Darmezin, L'approvisionnement en blé, s. 115.

${ }^{86}$ Por. Semple, Geographic Factors, s. 71-74; E.W. Bowen, Roman Commerce in the Early Empire, „The Classical Weekly” 21 (1928) 201; Semple, Ancient Mediterranean Agriculture. Part I, s. 81; L. Casson, The Role of the State in Rome's Grain Trade, „Memoirs of the American Academy in Rome" 36 (1980) passim; Rickman, The Grain Trade, s. 261-275; Casson, Maritime Trade, 
cesarstwa Rzym otrzymywał 83 tys. ton ziarna, które załadowywano na statki w aleksandryjskim porcie ${ }^{87}$. Podczas gdy dla Rzymian pszenica stanowiła podstawę żywieniową przez cały okres starożytności ${ }^{88}$, Grecy, mimo jej importu, musieli nadal sięgać również po inne dary Demeter, przede wszystkim po jęczmień ${ }^{89}$.

Jako produkt handlowy pszenica była najdroższym ze zbóż dostępnych na rynku. Za jej wysoką ceną stała ograniczona powierzchnia, na której możliwa była jej uprawa, wysokie koszty transportu oraz duży popyt ${ }^{90}$. $Z$ tego powodu $\mathrm{z}$ reguły pozostawała poza finansowym zasięgiem niższych warstw społecznych $^{91}$, osiagając mniej więcej dwukrotność ceny jęczmienia ${ }^{92}$. Co ciekawe,

s. 39; P. Erdkamp, The Grain Market in the Roman Empire. A Social, Political and Economic Study, Cambridge 2005, passim; Mazoye - Roudart, A History of World Agriculture, s. 169; D. Kessler P. Temin, The Organization of the Grain Trade in the Early Roman Empire, „The Economic History Review" 60 (2007) fasc. 2, 315-317; Toussaint-Samat, Historia naturalna, s. 138-139. Z Egiptu, jako głównego źródła dostaw, do VII w. korzystało Cesarstwo Bizantyńskie, por. M. Kokoszko T. Wolińska, Zaopatrzenie Konstantynopola w żywność, w: Konstantynopol - Nowy Rzym, s. 463; Kokoszko - Jagusiak, Zboża Bizancjum, s. 20-21.

${ }^{87} \mathrm{O}$ handlu egipskim zbożem Haas, Alexandria in Late Antiquity, s. 41-43.

${ }^{88}$ Por. Evans, Wheat Production, s. 428; Kessler - Temin, The Organization of the Grain, s. 313, 315; K. Killgrove - R.H. Tykot, Food for Rome. A Stable Isotope Investigation of Diet in the Imperial Period (1st-3rd centuries AD), ,Journal of Anthropological Archaeology” 32 (2013) 28. Nie oznacza to oczywiście, że nie jedli oni innych zbóż, był to głównie jęczmień, a w czasach głodu także proso, włośnica ber i owies, por. Kokoszko - Jagusiak, Pszenice antyku i Bizancjum, s. 33-34; ciż, Wheats of Antiquity and Byzantium, s. 36.

${ }^{89} \mathrm{~W}$ warunkach greckich zbożem, które dawało najlepsze plony, był właśnie jęczmień, por. Semple, Geographic Factors, s. 56-57; Winniczuk, Chleb u starożytnych, s. 225; Osborne, Classical Landscape, s. 99; Garnsey, Famine and Food, s. 11; Alcock, Food in the Ancient World, s. 751752. O różnicy kosztów produkcji jęczmienia w Rzymie i w Grecji por. Jasny, Competition Among Grains, s. 752-758. Jak zauważa G. Reger (The Public Purchase of Grain, s. 303-304), wbrew temu, co powszechnie sądzono, dla Greków okresu klasycznego, ale i hellenistycznego, to jęczmień a nie pszenica był nie tylko powszechniejszy w konsumpcji, ale nawet wyżej ceniony jako zboże bardziej tradycyjne i łatwiej dostępne. Rzadko jednak spożywano go pod postacią chleba. Odnośnie do dań przygotowywanych na bazie jęczmienia zob. A. Dalby - S. Grainger, The Classical Cookbook, London 1996, 52; M.-C. Amouretti, Urban and Rural Diets in Greece, w: Food. A Culinary History from Antiquity to the Present, s. 84; Dalby, Food in the Ancient World, s. 46-47; Kokoszko, Smaki Konstantynopola, s. 477-480; Kokoszko - Jagusiak, Zboża Bizancjum, s. 29-31. Ciasta z mąki jęczmiennej serwowano nawet podczas wystawnych bankietów, por. Dalby, Siren Feasts, s. 52-53.

${ }^{90}$ Por. Semple, Geographic Factors, s. 48.

${ }^{91}$ Por. Ph.P. Bober, Art, Culture, and Cuisine. Ancient and Medieval Gastronomy, Chicago London 1999, 206; Erdkamp, The Grain Market, s. 148; Wilkins - Hill, Food in the Ancient World, s. 2. Szczegółowa analiza spożycia pszenicy na gruncie podziału społecznego w oparciu o dane pochodzące z traktatów medycznych, głównie dzieł Galena, w: Kokoszko - Jagusiak, Pszenice antyku $i$ Bizancjum, s. 51-56; ciż, Wheats of Antiquity and Byzantium, s. 54-58.

${ }^{92}$ Jej ceny zależały od pory roku - tańsza była po żniwach, droższa przed nimi, por. Garnsey, Food and Society, s. 32. Cena pszenicy na Delos w 282 r. prz. Chr. wahała się między 4,5 a 10 drachm za medymnos (ok. 52 litry), por. Osborne, Classical Landscape, s. 47. W Rzymie w cza- 
nawet uprawiający ją rolnicy woleli sprzedać ją na miejskim targu dla wysokiego zysku, niż spożywać samemu ${ }^{93}$. W dużych ilościach konsumowano ją jedynie w miastach, w Grecji - zwłaszcza w Atenach, które polegały na imporcie $^{94}$. W Rzymie, w 123 r. prz. Chr., wprowadzono publiczną dystrybucję zboża - głównie właśnie $\pi$ pós - po zaniżonych cenach; od czasów Oktawiana Augusta rozdawano je za darmo. Cesarz Aurelian (270-275) zastąpił ziarno jego ekwiwalentem w chlebie. System ten utrzymał się przez ponad sześć wieków ${ }^{95}$ i dotyczył nie tylko stolicy cesarstwa, ale i miast leżących w jego prowincjach, w tym w egipskiej Aleksandrii ${ }^{96}$. W efekcie, paradoksalnie, mieszczanie spożywali więcej produktów zbożowych niż chłopi ${ }^{97}$. Na uwadze musimy mieć jednak jakość tych pokarmów, bowiem ich cena zależała od rodzaju wykorzystanego surowca, nakładu pracy włożonego w jego obróbkę i użytej technologii98. Ludność uboższa jadała zboże pszeniczne pod postacią gorszych gatunków chleba lub potraw gotowanych ${ }^{99}$, zaś białe pieczywo z najczystszej mąki zarezerwowane było dla społecznych elit ${ }^{100}$.

sach Cycerona i później, za Pliniusza Młodszego, musiała wynosić, w okresie przeciętnego urodzaju, 7 lub więcej sestercji za modius (ok. 8,73 litra), por. Jasny, Wheat Prices and Milling Costs, s. $137-170$.

${ }^{93}$ Wysiewali i jedli zboża gorszej jakości, łatwiejsze w uprawie i tańsze, por. Garnsey, Famine and Food, s. 51; tenże, Food and Society, s. 121; Erdkamp, The Grain Market, s. 157; Wilkins - Hill, Food in the Ancient World, s. 52 i 120. Mogły to być także pewne mniej plenne, ale lepiej dostosowane do warunków klimatycznych odmiany pszenicy, np. płaskurka, por. Kokoszko - Jagusiak, Pszenice antyku i Bizancjum, s. 52; ciż, Wheats of Antiquity and Byzantium, s. 54. Ta sprzedaż mogła wynikać również z faktu, iż pszenica jest zbożem trudnym do przechowywania. By nie ulec zepsuciu, wymaga niskiej temperatury i wilgotności powietrza, por. Rickman, The Grain Trade, s. 261-262.

${ }^{94}$ Por. Jasny, The Daily Bread, s. 232. Ci, którzy mieszkali poza miastem, zapewne nie spożywali pszenicy nawet w okresie prosperity Aten. Sytuacja przedstawiała się inaczej na obszarach, których warunki sprzyjały jej uprawie. Z tego względu w Rzymie produkty pszenne mogły dominować w diecie jego mieszkańców zanim jeszcze import tego zboża przybrał dużą skalę, por. tenże, Competition Among Grains, s. 755-756.

${ }^{95}$ Por. Winniczuk, Chleb u starożytnych, s. 239; A.J.B. Sirks, The Size of the Grain Distribution in Imperial Rome and Constantinople, „Athenaeum” 79 (1971) 215-225; Rickman, The Grain Trade, s. 263; Mazoye - Roudart, A History of World Agriculture, s. 253-254.

${ }^{96}$ Por. B. Bartlett, How Excessive Government Killed Ancient Rome, „Cato Journal” 14 (1994) fasc. 2, 290; Erdkamp, The Grain Market, s. 276.

${ }^{97}$ Por. Amouretti, Urban and Rural Diets, s. 85.

${ }^{98}$ Por. Kokoszko - Jagusiak, Pszenice antyku i Bizancjum, s. 53; ciż, Wheats of Antiquity and Byzantium, s. 55.

${ }^{99}$ Por. ciż, Pszenice antyku i Bizancjum, s. 54-56; ciż, Wheats of Antiquity and Byzantium, s. 56-58, co oczywiście nie oznacza, że nie jedzono gotowanych potraw zbożowych na terenach miejskich.

${ }^{100}$ Por. Neel - Pugh, Jedzenie i uczty Jezusa, s. 41; Erdkamp, The Grain Market, s. 309. Oznaką wysokiego statusu społecznego było kupowanie chleba zamiast pieczenie go samemu; jeśli miał być wypiekany w domu, bogaci zatrudniali wyspecjalizowanego piekarza, zob. Wilkins - Hill, Food in the Ancient World, s. 118; por. przeciwną opinię Erdkamp, The Grain Market, s. 135 i 252-253. 
Zarówno w Grecji ${ }^{101}$, jak i w Rzymie ${ }^{102}$, pszenica służyła za pokarm dla armii. Natomiast, ze względu na wysokie koszty, na ogół nie używano jej jako paszy dla zwierząt, sięgając w tym celu po jęczmień ${ }^{103}$.

$\mathrm{W}$ antyku pszenica wykorzystywana była w wielu recepturach kulinarnych $^{104}$. Z całych ziaren tego zboża przyrządzano gęste zupy, które zapewne

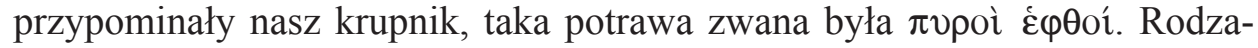
jem kleiku lub zupy była $\alpha \theta \dot{\jmath} \rho \alpha$ gotowana z płaskurki. Mielona mąka typu

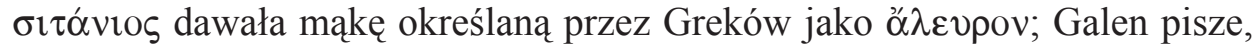
że za jego czasów wieśniacy robili z niej zupę, do której, dla wzbogacenia smaku i wartości, dolewali mleka. Pszenicę płaskurkę rozdrabniano do postaci

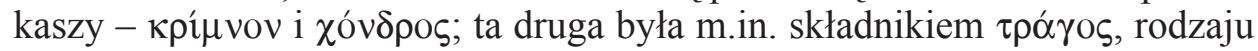
kluseczek, które suszono tak, by można je było długo przechowywać, a następnie zalewano wodą lub mlekiem i rozgotowywano do postaci zupy. Do zagęszczania sosów używano skrobi pszennej, پ’ $\mu v \lambda o v$. Pszenicę wykorzystywano do wypieku różnych słodkich ciast ${ }^{105}$. Produkowano $\mathrm{z}$ niej również piwo $^{106}$. Jednak - jak słusznie zauważa Felipe Fernandez-Armesto ${ }^{107}$ - gdyby

${ }^{101}$ Wspomina o tym Ksenofont, por. J.F. Lazenby, Logistics in Classical Greek Warfare, „War in History" 1 (1994) fasc. 3, 13.

102 Żołnierze rzymscy żywili się chlebem jęczmiennym tylko wtedy, gdy nie było dostaw pszenicy; w normalnych warunkach ich dieta opierała się na niej, zob. np.: C.G. Harcum, A Study of Dietetics among the Romans (Concluded), „The Classical Weekly” 12 (1918) fasc. 9, 66; R.W. Davies, The Roman Military Diet, „Britannia” 2 (1971) 133; P. Erdkamp, The Corn Supply of the Roman Armies during the Third and Second Centuries B.C., „Historia” 44 (1995) fasc. 2, 172; R. Quick - S.J. Simon, Wheat Production and the Romanization of Northern Gaul, ,The Ancient World” 30 (1999) fasc. 1, 59-62; J.P. Alcock, Food in Roman Britain, Stroud 2001, 17 i 155; H.E.M. Cool, Eating and Drinking in Roman Britain, Cambridge 2006, 78-79. Formą kary, np. za zhańbienie się w trakcie walki, były natomiast racje jęczmienia, por. Dalby, Siren Feasts, s. 91; Dalby - Grainger, The Classical Cookbook, s. 52; Garnsey, Food and Society, s. 120; Alcock, Food in Roman Britain, s. 30.

${ }^{103}$ Por. Jasny, Competition Among Grains, s. 755; Alcock, Food in Roman Britain, s. 18 i 29; M. Kokoszko - K. Jagusiak - Z. Rzeźnicka, Jęczmień, w: ciż, Dietetyka i sztuka kulinarna, cz. 1, s. 321-322; ciż, Barley, w: ciż, Cereals of Antiquity and Early Byzantine Times, s. 321-322. Byli jednak i tacy, którzy mogli sobie pozwolić na karmienie hodowanych przez siebie zwierząt paszą z pszenicy, por. Kokoszko - Jagusiak, Pszenice antyku i Bizancjum, s. 39-40; ciż, Wheats of Antiquity and Byzantium, s. 41-42.

${ }^{104}$ Dania przygotowywane na bazie pszenicy zostały wymienione i scharakteryzowane np. w: Dalby, Food in the Ancient World, s. 131-132 i 349; Alcock, Food in the Ancient World, s. 167168; Kokoszko, Smaki Konstantynopola, s. 475-476; Kokoszko - Jagusiak, Zboża Bizancjum, s. $22-$ 27; ciż, Pszenice antyku i Bizancjum, passim; ciż, Wheats of Antiquity and Byzantium, passim; Neel - Pugh, Jedzenie i uczty Jezusa, s. 21-165.

${ }^{105}$ Por. J. Solomon, ,, Tracta”. A Versatile Roman Pastry, „Hermes” 106 (1978) fasc. 4, 539-556.

${ }^{106}$ Por. Alcock, Food in the Ancient World, s. 175; Cool, Eating and Drinking, s. 141-143. Choć oczywiście podstawowym produktem do jego przyrządzania pozostawał jęczmień, zob. np. M. Kokoszko - K. Jagusiak, Woda, wino i tak dalej, czyli o napojach i trunkach w Konstantynopolu, „Przegląd Nauk Historycznych” 9 (2010) fasc. 1, 48-52.

${ }^{107}$ Por. Fernandez-Armesto, Near a Thousand Tables, s. 97. 
nie chleb, zaliczany do podstawowych elementów diety świata grecko-rzymskiego ${ }^{108}$, byłaby ona tylko jednym z wielu rywalizujących ze sobą zbóż. Swoją pierwszoplanową pozycję zawdzięczała zawartemu w niej glutenowi, który sprawiał, że powstała z niej mąka pozwalała na wyrośnięcie ciasta i tym samym dawała pulchne pieczywo ${ }^{109}$.

Na zakończenie ogólnych uwag na temat roli, jaką interesujące nas zboże odgrywało w życiu starożytnych, warto wspomnieć o miejscu zajmowanym przez nie w obrzędach sakralnych. Grecy i Rzymianie w kulcie najczęściej sięgali po jęczmień, zapewne dlatego, że pszenicę poznali znacznie później, a pozostali wierni pierwotnym rytuałom ${ }^{110}$. Jednak i ona miała $w$ tej sferze ich życia pewne znaczenie. W Grecji składano ją w ofierze Apollinowi w Delos ${ }^{111}$ i wykorzystywano w obrządkach w świątyni Demeter w Eleusis ${ }^{112}$. W obydwu tych antycznych kulturach pojawiała się jako element ceremonii weselnych ${ }^{113}$. Wraz z nastaniem chrześcijaństwa, pszenica i chleb stały się jednymi z głównych jego symboli ${ }^{114}$.

${ }^{108}$ Por. np. B.A. Sparkes, The Greek Kitchen, „The Journal of Hellenic Studies” 82 (1962) 123; Dalby - Grainger, The Classical Cookbook, s. 10-11; Garnsey, Food and Society, s. 18; D. Samuel, Bread in Archaeology, „Civilisations” 49 (2002) fasc. 1/2, 29; Dalby, Food in the Ancient World, s. 58-59; Cool, Eating and Drinking, s. 75; Kaufman, Cooking in Ancient, s. XXXVIII; Civitello, Cuisine and Culture, s. 25; Toussaint-Samat, Historia naturalna, s. 204-205; J.M. Wilkins, The Boastful Chef. The Discourse of Food in Ancient Greek Comedy, Oxford 2000, 167; Kokoszko, Smaki Konstantynopola, s. 483; Neel - Pugh, Jedzenie i uczty Jezusa, s. 40.

${ }^{109}$ O działaniu glutenu por. Moritz, ,Corn”, s. 135; O. Borowski, Eat, Drink and Be Merry. The Mediterranean Diet, „Near Eastern Archaeology” 67 (2004) fasc. 2, 99; Kaufman, Cooking in Ancient, s. XLII-XLIII; Kokoszko, Smaki Konstantynopola, s. 477; Kokoszko - Jagusiak, Pszenice antyku i Bizancjum, passim; ciż, Wheats of Antiquity and Byzantium, passim. Chleb na zakwasie był wspomniany przez pisarzy greckich na początku epoki klasycznej, ale tylko jako rarytas, por. Jasny, The Daily Bread, s. 249. Pozostaje tajemnica, w jaki sposób starożytni odkryli działanie drożdży, por. Kaufman, Cooking in Ancient, s. XLV-XLVI. Drugie co do popularności zboże antyku - jęczmień - musiało być prażone w celu pozbawienia go łuski i przygotowania do spożycia. Proces ten niszczył zawarty w nim gluten i był przyczyną słabej jakości, płaskiego wypieku, Alcock, Food in the Ancient World, s. 33; Wilkins - Hill, Food in the Ancient World, s. 52-53.

${ }^{110}$ Por. Semple, Geographic Factors, s. 48; Winniczuk, Chleb u starożytnych, s. 233.

${ }^{111}$ Por. Wilkins - Hill, Food in the Ancient World, s. 105.

${ }^{112}$ Por. Toussaint-Samat, Historia naturalna, s. 130; Wilkins, The Boastful Chef, s. 108.

${ }^{113}$ Por. Wilkins - Hill, Food in the Ancient World, s. 118; V. Tsoukala, Cereal Processing and the Performance of Gender in Archaic and Classical Greece: Iconography and Function of a Group of Terracotta Statuettes and Vases, w: SOMA 2007. Proceedings of the XI Symposium on Mediterranean Archaeology, Istanbul Technical University, 24 and 29 April 2007, ed. Ç.Ö. Aygün, Oxford 2009, 390.

${ }^{114}$ D. Forstner, Świat symboliki chrześcijańskiej, przekł. i oprac. W. Zakrzewska - P. Pachciarek - R. Turzyński, Warszawa 1990, 455-459; Garnsey, Food and Society, s. 18 i 121; Neel - Pugh, Jedzenie i uczty Jezusa, s. 43 i 166. 
„Chleb będący Jego ciałem jest zmartwychwstaniem, podobnie jak zmartwychwstaniem wysiane ziarno pszenicy. Ciało Pańskie powstaje na nowo w ogniu ku radości Kościoła, jak świeżo upieczony chleb"115.

- tak mistyczny sens chleba i pszenicy wyjaśnia Klemens Aleksandryjski.

5. Nauka Galena na temat chleba pszennego. Na wstępie wypada zaznaczyć, że Galen nie był pierwszym medykiem, który wypowiadał się w kwestii właściwości chleba wypiekanego z mąki pszennej. Bogactwo informacji na temat pszenicy, a zatem także przygotowywanego z niej pieczywa, odnajdujemy już traktatach zawartych w Corpus Hippocraticum, na przykład w De diaeta ${ }^{116}$. Podobnych danych nie poskąpił potomnym również Dioskurides, lekarz żyjący w I w. po Chr., autor m.in. dzieła zatytułowanego De materia medica ${ }^{117}$. Źródłem o nieocenionej wartości dla wszystkich, którzy badają antyczną kuchnię, jest Uczta mędrców ( $\Delta \varepsilon i \pi v o \sigma o \varphi \imath \sigma \tau \alpha i ́)$, skomponowana w 2. poł. II w. po Chr. przez Atenajosa $z$ Naukratis ${ }^{118}$. Ta monumentalnych rozmiarów praca szeroko traktuje o jedzeniu i jego spożywaniu. Jej autor przytacza w niej niezliczone historie, anegdoty i cytaty, pochodzące również od współczesnych mu i poprzedzających jego epokę autorów medycznych. Od niego dowiadujemy się także o pisarzach, którzy pieczywu poświęcali osobne dzieła ${ }^{119}$. Sam Atenajos, w przedmiocie interesującego nas chleba, wymienia ponad siedemdziesiąt jego rodzajów - z reguły ekskluzywnych ${ }^{120}$.

a) Dane kulinarne na temat chleba pszennego. Galen zaznacza, że chleb,

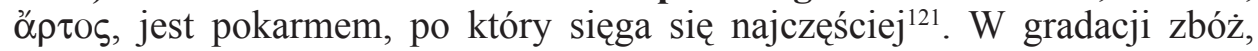
z których można go wypiekać, czołowe miejsce zajmuje u Pergamończyka pszenica zwyczajna, gdyż to głównie pieczywu z niej uzyskiwanemu poświęca on uwagę w jednym z rozdziałów De alimentorum facultatibus ${ }^{122}$. Chleby

${ }^{115}$ Clemens Alexandrinus, Paedagogus I 6, 46, ed. H.I. Marrou - M. Harl, SCh 70, Paris 1960 , 194, thum. Szarmach, s. 45.

${ }^{116}$ Odnośnie do szczegółów por. Kokoszko - Jagusiak, Pszenice antyku i Bizancjum, s. 56-57 i 117-118; ciż, Wheats of Antiquity and Byzantium, s. 58-60 i 120-121.

${ }^{117}$ O Dioskuridesie patrz: Kokoszko, Ryby i ich znaczenie, s. 12; J. Scarborough, Dioskourides of Anazarbos, w: The Encyclopedia of Ancient Natural Scientists, s. 271-273. Szczegóły dotyczące nauki Dioskuridesa na temat właściwości chleba pszennego w: Kokoszko - Jagusiak, Pszenice antyku i Bizancjum, s. 118-119 i 191-192; ciż, Wheats of Antiquity and Byzantium, s. 121-122 i 193-195.

${ }^{118} \mathrm{Na}$ temat Atenajosa zob. m.in. w: Kokoszko, Ryby i ich znaczenie, s. 10-12; Kokoszko Jagusiak - Rzeźnicka, Dietetyka i sztuka kulinarna, cz. 1, s. 573. O wadze jego pracy dla poznania doktryn dietetycznych i kulinariów tej epoki w: ciż, Pszenice antyku i Bizancjum, s. 24-26; ciż, Wheats of Antiquity and Byzantium, s. 26-28.

${ }^{119}$ Powstawały one m.in. w Aleksandrii, por. Winniczuk, Chleb u starożytnych, s. 240.

${ }^{120}$ Wymienia je w III księdze swojej Uczty, zob. m.in. w: Garnsey, Food and Society, s. 121; Kokoszko - Jagusiak, Pszenice antyku i Bizancjum, s. 114-116, 185-186, 257-258 i 262-263; ciż, Wheats of Antiquity and Byzantium, s. 117-119, 188-189, 260 i 264-265.

${ }^{121}$ Por. Galenus, De alimentorum facultatibus 493, 14-16.

${ }^{122}$ Por. tamże 480, 13 - 490, 8. Chodzi o rozdział zatytułowany Пврì $\pi v \rho \hat{v} v$, czyli $O$ pszenicy. 
z innych mąk, jak możemy wnioskować z rozważań medyka, jedzono tylko wtedy, gdy brakowało wypieku pszennego lub w sytuacjach, w których był on, jako produkt $\mathrm{z}$ dość drogiego surowca, poza zasięgiem finansowym nabywcy. Z narracji naszego autora wynika ponadto, iż dobrze wyrośnięty, biały ő $\rho \tau$ ๙os $\pi$ úpıvos spożywali przede wszystkim mieszkańcy miast, bowiem to na ich potrzeby uprawiano zboże zwane $\pi v \rho o ́ \varsigma^{123}$. Ich też Galen określa mianem jego

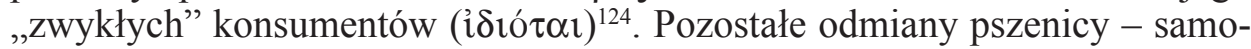
psza, płaskurka, orkisz - musiały trafiać na stoły wieśniaków ${ }^{125}$. Ci ostatni, jak choćby świętujący rolnicy wzmiankowani w De alimentorum facultatibus ${ }^{126}$, jadali z reguły chleb przaśny ${ }^{127}$. Ze słów Galena wysnuć możemy wniosek, iż w ciagu roku zdarzały się dni, kiedy to mieszkańcy wsi w ogóle nie spożywali pieczywa. Stał za tym choćby fakt, iż zajęci pracą w polu nie mieli czasu na podjęcie pracochłonnego i długotrwałego procesu jego wypieku. Gotowali wówczas całe ziarna pszenicy, sporządzając $\pi v \rho o i ̀ ~ \varepsilon \varphi \theta o^{128}$, lub przygotowywali zupę z ớ $\lambda \varepsilon v \rho o v$ i mleka ${ }^{129}$.

Pisma Pergamończyka, mimo iż ten koncentruje się na medycznych własnościach omawianych pokarmów, dostarczają wielu informacji dotyczących sposobów przygotowywania pożywienia. Zasada ta sprawdza się m.in. odnośnie do interesującego nas chleba. Lekarz, dbając o to, by finalny produkt był jak najlepszej jakości, zaleca, by ci, którzy mają zamiar go sporządzić, mieli na uwadze właściwości pszennego ziarna, jakim dysponują ${ }^{130}$. W Galenowych traktach, które analizujemy, brak szczegółów na temat technologii produkcji

${ }^{123} \mathrm{~W}$ dziełach Galena jest wiele bezpośrednich wskazówek, które pozwalają twierdzić, iż odbiorcami tego zboża była właśnie ludność miejska, np. tamże 518, 3-4.

${ }^{124}$ Por. tamże 486, 1.

${ }^{125}$ Zaznaczyć jednak należy, że powszechnie ceniono, a więc i nabywano w miastach wypieki z pszenicy samopszy (lecz tylko świeżo wyjęte z pieca - por. tamże 518, 8) i z orkiszu. Co do tego

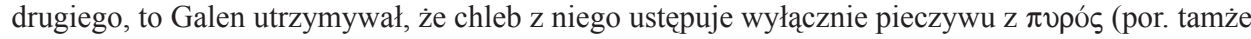
$518,4)$, jednak pod warunkiem wykorzystania dobrej jakości zboża (por. tamże 518, 4-5).

${ }^{126}$ Por. tamże 486, 4.

${ }^{127}$ Por. tamże 486, 5.

${ }^{128}$ Por. tamże 494, 16 - 496, 2.

${ }^{129}$ Por. tamże 498, 5 - 500, 3.

${ }^{130}$ Por. tamże 480, 14 - 482, 4. Informacje dotyczące cech najlepszego i najgorszego ziarna Galen zamieścił w De alimentorum facultatibus przed rozważaniami na temat pieczywa pszennego. Podobnie postąpił w De victu attenuante, we fragmencie omawiającym produkty z pszenicy (De victu attenuante 33, 1 - 34, 1, korzystamy z wydania: Galeni De victu attenuante, ed. K. Kalbfleisch, Leipzig - Berlin 1923). Uczynił tak, ponieważ proces wypieku chleba zawsze zaczynał się od zmielenia zboża, nawet wówczas, gdy odbywał się w gospodarstwie domowym. Pracę tę, zarówno w Grecji, jak i w Rzymie, z reguły wykonywały kobiety. Jedynie bogaci mogli pozwolić sobie na to, by obciążyć nią niewolników, których nadzorowała pani domu, por. Winniczuk, Chleb u starożytnych, s. 228-229; R.I. Curtis, Ancient Food Technology, Leiden - Boston - Köln 2001, 281 i 348349; Kaufman, Cooking in Ancient, s. XXXVI; Wilkins - Hill, Food in the Ancient World, s. 77 i 124; Toussaint-Samat, Historia naturalna, s. 137-138; Tsoukala, Cereal Processing, s. 387-395. Zajęcie to, ze względu na ówczesną technologię wykonywane na klęczkach, dewastowało układ 
mąki typu ő $\lambda \varepsilon v \rho o v$ i $\sigma \varepsilon \mu i ́ \delta \alpha \lambda ı \varsigma$, niemniej jednak napotykamy tutaj na pewne związane z tym dane. Dowiadujemy się więc, że po zmieleniu zboża ${ }^{131}$ przesiewa się powstałą tak mąkę ${ }^{132}$, by oddzielić ở $\lambda \varepsilon v \rho o v^{133}$ i otręby $(\pi i \tau v \rho \alpha)^{134}$. Medyk tłumaczy, że czysta mąka pozwala na wypiek najwartościowszego bia-

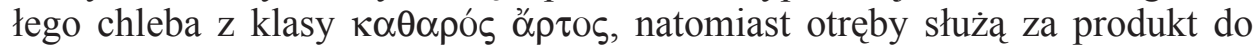

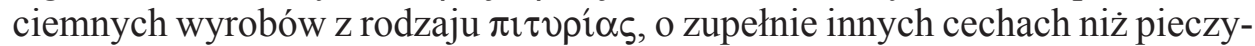
wo poprzednio wspomniane ${ }^{135}$. Dalej czytamy, iż można w ogóle zrezygnować z przesiewania rozdrobnionej pszenicy; uzyskany wówczas półprodukt nadaje

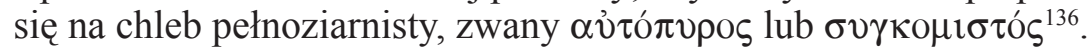

W przeciwieństwie do Atenajosa z Naukratis, Galen nie stawiał sobie za cel wymienienia jak największej liczby znanych gatunków chleba, ale skupił się na omówieniu tych podstawowych. Przy tej okazji przedstawił obowiązujące za jego czasów zasady dietetycznej ewaluacji pieczywa. Przyjęta przez niego systematyka żywieniowo-kulinarna dzieli chleby pszenne według trzech kryteriów ${ }^{137}$ : rodzaju użytej mąki, obecności lub braku drożdży / zaczy-

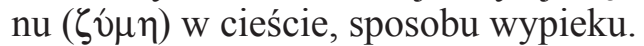

Pierwsza kategoria, częściowo już przez nas zarysowana powyżej, wyróżniała chleby białe i czarne. Dobrze oczyszczona mąka dawała jasne pieczywo $^{138}$, zaś im więcej było w niej zanieczyszczeń - przede wszystkim otrąb, ale i wszystkiego tego, co było na i w ziarnie ${ }^{139}$ - tym ciemniejszy wychodził

kostny, o czym świadczą zwyrodnienia damskich szkieletów odnajdywanych na stanowiskach archeologicznych, por. Cool, Eating and Drinking, s. 74.

${ }^{131}$ Por. Galenus, De alimentorum facultatibus 481, 13-14. Początkowo ziarno rozgniatano w olbrzymich moździerzach. Z czasem zaczęto rozcierać je pomiędzy dwoma kamieniami - najprawdopodobniej najpierw obracano górny rękoma, by później wprowadzić ulepszenie w postaci uchwytu, który pozwalał wprawiać tarczę w ruch. Znano różne rozmiary takich młynków. Stopniowo dodawano kolejne udogodnienia, jak wykorzystanie pracy zwierząt. Wreszcie pojawiły się młyny wodne, szerzej zob. Jasny, Wheat Prices and Milling Costs, s. 149-151; tenże, The Daily Bread, s. 233-244; Winniczuk, Chleb u starożytnych, s. 227-232; L.A. Moritz, Grain Mills and Flour in Classical Antiquity, Oxford 1958; Sparkes, The Greek Kitchen, s. 125; Curtis, Ancient Food Technology, s. 279289 i $335-358$.

${ }^{132}$ Por. Galenus, De alimentorum facultatibus 481, 14. Odnośnie do szczegółów dotyczących przesiewania mąki odsyłamy do literatury przedmiotu, m.in.: Jasny, Wheat Prices and Milling Costs, s. 150-151; tenże, The Daily Bread, s. 242-243; Curtis, Ancient Food Technology, s. 291 i 362; Alcock, Food in the Ancient World, s. 112-113.

${ }^{133}$ Por. Galenus, De alimentorum facultatibus 481, 14.

${ }^{134}$ Por. tamże 481, 13.

${ }^{135}$ Por. tamże 482, 5-16.

${ }^{136}$ Por. tamże 483, 1-12.

${ }^{137}$ Są to kryteria recepturalne i technologiczne.

${ }^{138}$ Pamiętać jednak musimy, że antyczny biały chleb nie mógł równać się jakością - m.in. pod względem koloru wypieku - z dzisiejszym. Naum Jasny (Wheat Prices and Milling Costs, s. 149; The Daily Bread, s. 246) podkreśla, że dobrze oczyszczona, biała mąka była wówczas olbrzymią rzadkością.

${ }^{139}$ Mąka mogła być zanieczyszczona kamiennymi fragmentami żaren, które trafiły do niej w trakcie mielenia ziarna. Posiadamy na to materialne dowody w postaci starożytnych szkieletów 
chleb i mniejsza była jego wartość. Między tymi dwiema skrajnościami, jak pisał Pergamończyk, występowała cała rozpiętość chlebów różniących się wyglądem i właściwościami dietetycznymi ${ }^{140}$. Srodek skali, co zaznaczył medyk, stanowiły wypieki typu $\alpha$ $\tau o ́ \pi v \rho o \varsigma / \sigma v \gamma \kappa o \mu \imath \sigma \tau o ́ \varsigma^{141}$. Pełna typologia

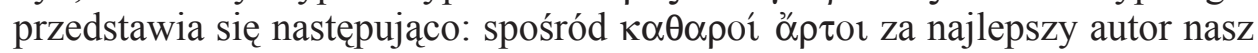
uznał $\sigma \imath \lambda \iota \gamma v^{\prime} \imath \tau \varsigma^{142}$; zaraz za nim wymienił chleb typu $\sigma \varepsilon \mu \imath \delta \alpha \lambda i \tau \eta \varsigma^{143}$; trzecie

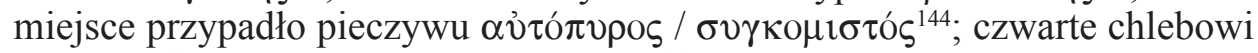

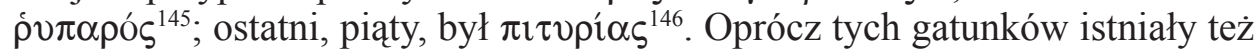

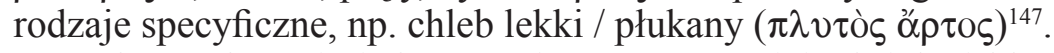

Lekarz, choć nie informował o tym w swojej oficjalnej klasyfikacji, stosował również podział pieczywa ze względu na grubość mąki użytej do jego wyrobu. Wszystkie wymienione powyżej typy chlebów produkowano z jej drobnej odmiany, a więc z ö $\lambda \varepsilon v \rho o v$. Jednak sporządzano wypieki także ze

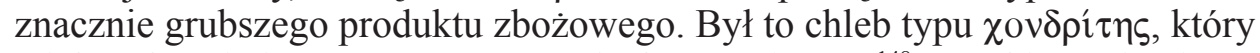
- jak wskazuje jego nazwa - powstał z kaszy $\chi o ́ v \delta \rho o \varsigma^{148}$, uzyskiwanej najczęściej z pszenicy $\pi$ upós.

Według kolejnej kategorii pieczywo dzieliło się na takie, do którego do-

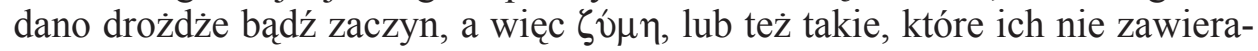
ło. Pierwszy rodzaj wypieku zwykle określany jest przez autorów dietetycz-

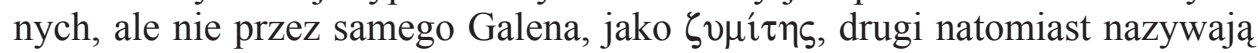

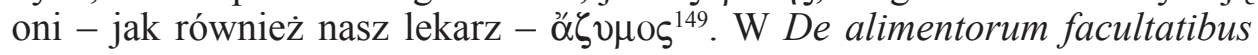
brak szczegółów na temat procesu spulchniania ciasta, dowiadujemy się natomiast, iż Galen uważa chleb wyrośnięty za lepszy od przaśnego ${ }^{150}$. Wypieki

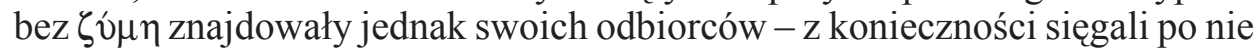

\footnotetext{
z mocno pościeranymi zębami, por. Jasny, Wheat Prices and Milling Costs, s. 149; Alcock, Food in the Ancient World, s. 113; Cool, Eating and Drinking, s. 75. Trafiały do niej również zanieczyszczenia znajdujące się na ziarnach, owady pasożytnicze i ich odchody, nasiona chwastów, toksyczne pleśni i grzyby. Ponadto, źle przechowywane zboże zaczynało kiełkować i gnić, por. D. Gourevitch, Le pain des Romains à l'apogée de l'Empire. Bilan entomo- et botano-archéologique, „Comptes rendus des séances de l'Académie des Inscriptions et Belles-Lettres" 149 (2005) fasc. 1, 29-38. Niekiedy myto ziarno przed mieleniem, nie wiemy jednak, czy robiono to regularnie, por. Jasny, Wheat Prices and Milling Costs, s. 150.

${ }^{140}$ Por. Galenus, De alimentorum facultatibus 482, 13-15.

${ }^{141}$ Por. tamże 483, 1-2.

${ }^{142}$ Por. tamże 484, 1.

${ }^{143}$ Por. tamże 484, 2.

${ }^{144}$ Por. tamże.

${ }^{145}$ Por. tamże 484, 3.

${ }^{146}$ Por. tamże 484, 4.

${ }^{147}$ Por. tamże 494, 9 - 496, 2.

${ }_{148}$ Por. tamże 496, 14-16. Kasza ta musiała więc być stosunkowo drobna, skoro nadawała się do zagniecenia wystarczająco spójnego ciasta, by móc z niego przyrządzić chleb.

${ }^{149}$ Por. tamże 486, 5.

${ }^{150}$ Por. tamże 485, 4 - 487, 10.
} 
np. ubodzy mieszkańcy wsi ${ }^{151}$, z wyboru zaś sportowcy, mający specyficzne wymagania dietetyczne ${ }^{152}$.

Zgodnie z trzecim podziałem, odnoszącym się do technologii pieczenia,

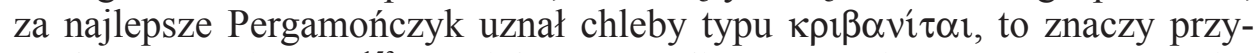

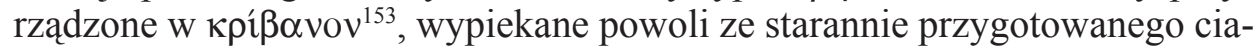
$\mathrm{sta}^{154}$. Za nimi plasowały się wypieki typu $i \pi v i \tau \alpha{ }^{155}$, sporządzone według najlepszej receptury ${ }^{156}$. Następnie wymienione zostały, znane Galenowi w dwóch odmianach, chleby pieczone na $\varepsilon \sigma \chi \alpha ́ \alpha \alpha^{157} \mathrm{i}$ z tej przyczyny nazywane ogólnie

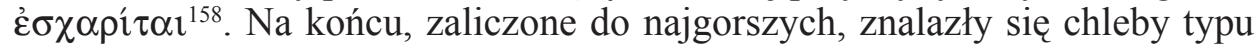

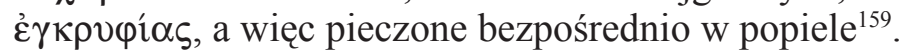

Ta ostatnia klasyfikacja wskazuje na trudności, jakie starożytni mieli z wypiekiem dobrej jakości pieczywa. Problemem było zwłaszcza utrzymanie właściwej temperatury zapewniającej równomierność pieczenia. Galen poświęcił temu zagadnieniu stosunkowo dużo uwagi, wyjaśniając, co stanie się z ciastem w trakcie poddawania go obróbce termicznej zarówno wtedy, gdy temperatura będzie zbyt wysoka, jak i wówczas, gdy nie osiągnie wystarczającej wartości. W pierwszym przypadku powierzchnia chleba stwardnieje niczym ścianki wypalanych naczyń ceramicznych, i podczas gdy jego skórka zrobi się sucha i podobna do wyschniętej gliny, środek pozostanie niedopieczony ${ }^{160}$. W drugim przypadku ciasto, zwłaszcza wewnątrz bochenka, będzie surowe ${ }^{161}$. Wobec tego, tylko ten, kto przez dłuższy czas zdoła utrzymać ogień na takim

${ }^{151}$ Por. tamże 486, 4.

152 Por. tamże 487, 15 - 488, 1.

${ }^{153}$ Kpíßovov - przenośny piekarnik ceramiczny w kształcie kopuły, używany głównie do wypieku chleba. Po włożeniu do środka ciasta, naczynie zasypywano żarem, por. Dalby, Food in the Ancient World, s. 101.

${ }^{154}$ Por. Galenus, De alimentorum facultatibus 489, 8-10.

${ }^{155}$ Nazwa tych wypieków pochodzi od greckiego słowa i̇vós, oznaczającego rodzaj małego, glinianego piekarnika na nóżkach, ze sklepioną pokrywą otwartą z jednej strony. Węgiel drzewny wsypywano w nim do płytkiego pojemnika mieszczącego się pod dnem; dopływ powietrza, tak, by mogło ono podtrzymywać żar, był zapewniony. Szczelina w tylnej części dna pozwalała ciepłu dostać się do wnętrza komory, w której umieszczano ciasto, por. Sparkes, The Greek Kitchen, s. 127-128; Curtis, Ancient Food Technology, s. 293; Dalby, Food in the Ancient World, s. 101-102; R. Westgate, Space and Social Complexity in Greece from the Early Iron Age to the Classical Period, „Hesperia” 84 (2015) fasc. 1, 74.

${ }^{156}$ Por. Galenus, De alimentorum facultatibus 489, 10-12.

${ }^{157}$ E $\sigma \chi \alpha ́ \rho \alpha$ - palenisko utworzone po usunięciu górnej pokrywy przenośnego piekarnika, por. Sparkes, The Greek Kitchen, s. 129; S.I. Rotroff - J.H. Oakley, Debris from a Public Dining Place in the Athenian Agora, Princeton 1992, 47-48 i 120-121.

${ }_{158}$ Por. Galenus, De alimentorum facultatibus 489, 12-15.

${ }^{159}$ Por. tamże 489, 15 - 490, 1. Galen nie wyjaśnił, jakie konkretne cech popiołu są szczególnie niepożądane. Być może chodziło o łatwość przypalenia ciasta przy zastosowaniu tej prymitywnej technologii.

${ }^{160}$ Por. tamże 484, 8-11.

${ }^{161}$ Por. tamże 484, 11-13. 
samym poziomie, uzyska wartościowy z punktu widzenia dietetyki chleb ${ }^{162}$. Potwierdzenie wagi przedstawionego problemu znajdujemy w Wychowawcy Klemensa Aleksandryjskiego. Scholarcha, thumacząc, co warunkuje trawienie i wydalanie pokarmu przez organizm człowieka, porównuje niewłaściwy przebieg tego procesu do wyrzucania niewypieczonego, pochodzącego z chłodnego pieca chleba - całego lub tylko jego środka ${ }^{163}$.

b) Ocena dietetyczna chleba pszennego. Biorąc pod uwagę wartość dietetyczną, Galen uznaje chleb za jedyną godną polecenia formę przyrządzania pszenicy $\pi v \rho o ́ \varsigma^{164}$, zwłaszcza w zestawieniu z metodą opartą na gotowaniu produktów pszenicznych, którą to uważa za niewłaściwą ${ }^{165}$. Jakość chleba medyk uzależnia od technologii wypieku, polecając zwłaszcza $\kappa \rho^{\prime} \beta \alpha v v^{166}$, a z pewnymi zastrzeżeniami także i $\pi v o ́ \varsigma^{167}$, oraz od użycia odpowiedniej ilości drożdży $(\zeta ̛ ́ \mu \eta)^{168}$ i soli $(\ddot{\alpha} \lambda \varepsilon \varsigma)^{169}$.

Pergamończyk utrzymuje, iż najbardziej lekkostrawne są chleby z naj-

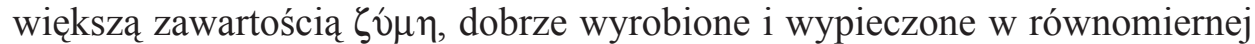
temperaturze $\mathrm{w} \kappa \rho^{\prime} \beta \alpha v \mathrm{v}^{170}$. Pieczywo z niewystarczającą ilością zaczynu lub całkowicie go pozbawione nie służy nikomu ${ }^{171}$. Chleb z dodatkiem sera ${ }^{172}$, jedzony $\mathrm{w}$ czasie świąt przez rolników ${ }^{173}$ i nazywany przez nich przaśnym $(\alpha \zeta \zeta v \mu \varsigma)^{174}$, szkodzi nawet najsilniejszym z nich ${ }^{175}$.

Wobec powyższego, gradacja poszczególnych gatunków chleba według ich pożywności, zaprezentowana przez Galena w De alimentorum facultatibus, przedstawia się następująco: za najpożywniejszy uznany zostaje $\sigma \imath \lambda \imath \gamma v^{\prime} \tau \eta \varsigma^{176}$; za nim zaś $\sigma \varepsilon \mu 1 \delta \alpha \lambda i ́ \tau \eta \varsigma^{177}$; trzecie miejsce zajmuje $\sigma v \gamma \kappa o \mu \imath \sigma \tau \varsigma^{178}$; czwarte $\rho v \pi \alpha \rho o ́ \varsigma^{179}$; ostatni w tej klasyfikacji, oceniony jako najmniej pożywny,

${ }^{162}$ Por. tamże 484, 13-14.

${ }^{163}$ Por. Clemens Alexandrinus, Paedagogus III 11, 65.

${ }^{164}$ Por. Galenus, De victu attenuante 32, 5-6.

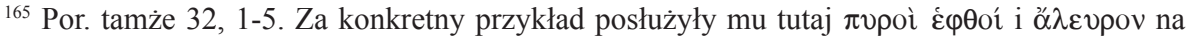
wodzie lub mleku.

${ }^{166}$ Por. tamże 32, 7.

${ }^{167}$ Por. tamże.

${ }^{168}$ Por. tamże 32, 6.

${ }^{169}$ Por. tamże 32, 6-7.

${ }^{170}$ Por. tenże, De alimentorum facultatibus 484, 6-8. Kontynuując narrację, Galen formułuje podobne uwagi, por. tamże 484, 13 - 485, 3; 486, $1-2$.

${ }^{171}$ Por. tamże 486, 2-3.

172 Por. tamże 486, 3.

${ }^{173}$ Por. tamże 486, 4.

${ }^{174}$ Por. tamże 486, 5.

${ }^{175}$ Por. tamże 486, 6-7.

${ }^{176}$ Por. tamże 484, 1.

177 Por. tamże 484, 2.

178 Por. tamże.

${ }^{179}$ Por. tamże 484, 3. 
jest $\pi \imath \tau v \rho{ }^{\prime} \alpha \varsigma^{180}$. Zauważyć musimy, iż ten porządek pozostaje w zgodzie ze stworzoną przez medyka klasyfikacją gatunków chleba pod względem rodzaju mąki użytej do ich wypieku.

c) Rola chleba pszennego w procedurach medycznych. Analizując pisma Galena, autora-lekarza, nie wypada nam krótko nie wspomnieć o miejscu, jakie - według niego - zajmowało pieczywo pszenne w procedurach medycznych ${ }^{181}$.

Medyk uznawał dobrej jakości wypieki z białej mąki za pokarm wyjątkowo zdrowy, dlatego zalecał je w wielu dietach i wymieniał jako składnik różnego rodzaju $\varphi \alpha ́ \rho \mu \alpha \kappa \alpha$. Pszenne chleby oceniał jako stosunkowo łatwe do strawienia i bardzo pożywne; pozwalały one - jak utrzymywał - na szybką regenerację organizmu, nie powodując przy tym zakłócenia równowagi humoralnej. Doskonale więc nadawać się miały dla osób ciężko chorych ${ }^{182}$.

Obecność pieczywa pszennego w niektórych dietach została szczególnie uwypuklona. Dla przykładu podać możemy, iż pojawia się ono jako lek na różnego rodzaju bóle głowy ${ }^{183}$. Często stanowi także składnik środków, ßo$\eta \theta \eta \dot{\mu} \mu \tau \alpha$, stosowanych zewnętrznie, z których większość Galen klasyfikował jako kataplazmy ${ }^{184}$. Ich funkcja lecznicza była wieloraka, od antidotum na rope W organizmie poczynając ${ }^{185}$, na remedium na dolegliwości oczu kończąc ${ }^{186}$.

d) Prezentacja poszczególnych gatunków chleba pszennego. Przystąimy teraz do szczegółowej prezentacji kulinarno-dietetycznej tych gatunków pieczywa pszennego, które można by utożsamić z chlebem wspomnianym przez Klemensa Aleksandryjskiego.

${ }^{180}$ Por. tamże 484, 4. Z drugiej jednak strony, Galen uważał, że ten gatunek najskuteczniej pobudza pracę jelit (por. tamże 484, 4-5).

${ }^{181}$ Szerzej zob. Kokoszko - Jagusiak, Pszenice antyku i Bizancjum, s. 196-199; ciż, Wheats of Antiquity and Byzantium, s. 199-202.

${ }^{182}$ Por. Galenus, In Hippocratis de victu acutorum commentaria IV 455, 2-4, korzystamy z wydania: Galeni In Hippocratis de victu acutorum commentaria libri IV, ed. I. Mewaldt - G. Helmreich - I. Westenberger, w: Galeni In Hippocratis de natura hominis, In Hippocratis de victu acutorum, De diaeta Hippocratis, In morbis acutis, Lipsiae - Berolini 1914, 115-366; tenże, De compositione medicamentorum secundum locos libri X 909, 15, korzystamy z wydania: Galeni De compositione medicamentorum secundum locos libri X, ed. C.G. Kühn, w: Claudii Galeni Opera omnia, vol. 12, Lipsiae 1826, 378-1007; vol. 13, Lipsiae 1827, 1-361.

${ }^{183}$ Choćby te spowodowane nadmiarem alkoholu (por. Galenus, De compositione medicamentorum secundum locos libri X 514, 4 - 520,6) czy zaburzeniami pracy przewodu pokarmowego (por. tamże 535, 10 - 541,2).

${ }^{184}$ Lekarz miał tutaj zwykle na myśli środki przygotowane z dobrej jakości, a więc mocno wy-

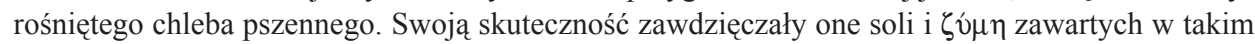
pieczywie i ułatwiających rozkład niebezpiecznych soków, por. Galenus, De simplicium medicamentorum temperamentis ac facultatibus libri XI 733, 2-3 (korzystamy z wydania: Galeni De simplicium medicamentorum temperamentis ac facultatibus libri XI, w: Claudii Galeni Opera omnia, ed. C.G. Kühn, vol. 11, Lipsiae 1826, 379-892; vol. 12, Lipsiae 1827, 1-377).

${ }^{185}$ Por. tamże 733, 4-6.

${ }^{186}$ Por. tamże 790, 10 - 792, 18. 
Nim to uczynimy, wyeliminujmy rodzaje nieposiadające wymienionych przez Scholarchę cech. Przypomnijmy, że w Wychowawcy mowa jest o chlebie $\mathrm{z}$ przesianego ziarna pszennego, które $\mathrm{w}$ trakcie tego procesu utraciło to, co było w nim odżywcze ( $\tau \rho o ́ \varphi ı \mu o v)$. Powstały w ten sposób produkt scharakte-

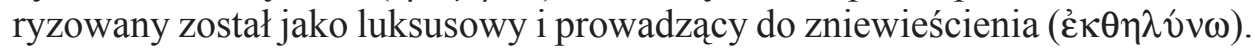

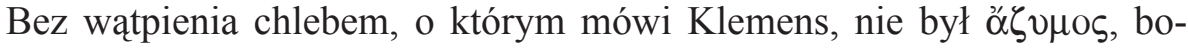
wiem pozbawiony drożdży lub zakwasu nie mógł wyrosnąć, a co się z tym wiąże, nie uchodził za luksus spożywczy ${ }^{187}$. Biorąc pod uwagę technologię

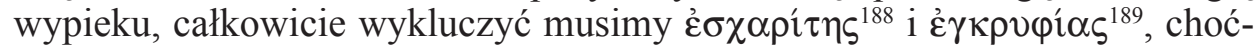
by ze względu na to, iż bezpośredni kontakt $\mathrm{z}$ popiołem zanieczyszczał je

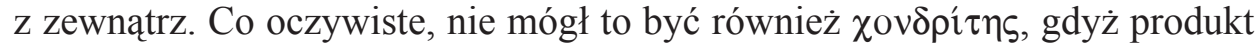
zbożowy, z którego go przygotowywano, nie był przesiewany - była to kasza, a nie mąka ${ }^{190}$.

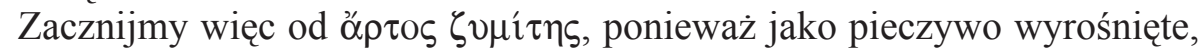
był on w czasach, o których mówimy, towarem ekskluzywnym. Za wzrost ciasta, z którego go wypiekano, odpowiadały dodane do niego drożdże ${ }^{191}$. Ponadto, warunkowały one wartości dietetyczne wypieku. Z rozważań Galena ${ }^{192}$ możemy wnioskować, że receptura i technologia pieczenia tego typu chleba były zbliżone do tych, które dotyczyły ö $\rho \tau o \zeta \kappa \alpha \theta \alpha \rho o ́ \varsigma^{193}$. Biorąc pod uwagę

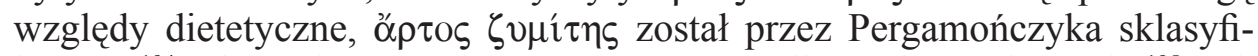
kowany ${ }^{194}$ jako pokarm nadający się zarówno dla osób w sile wieku ${ }^{195}$, jak i starszych ${ }^{196}$. Medyk podkreślał, że chleb ten - jeśli tylko został odpowiednio

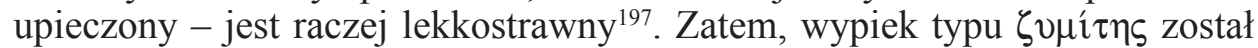
przez Galena przedstawiony jako wyraźnie lepszy od $\alpha \zeta \zeta \mu \circ \varsigma^{198}$.

Ciasto na dobrej jakości chleb musiało być poddane obróbce termicznej

${ }^{187}$ Co do jego charakterystyki autorstwa Galena zob. Kokoszko - Jagusiak, Pszenice antyku $i$ Bizancjum, s. 65-68; ciż, Wheats of Antiquity and Byzantium, s. 68-70.

${ }^{188}$ Galen (De alimentorum facultatibus 489, 12-15) zauważa, że w wyniku pieczenia ich na

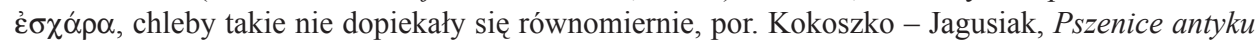
$i$ Bizancjum, s. 68-69; ciż, Wheats of Antiquity and Byzantium, s. 71.

189 Zdaniem Galena (De alimentorum facultatibus 490, 1) takie pieczywo przejmowało właściwości popiołu; zapewne też przypiekało się nadmiernie, por. Kokoszko - Jagusiak, Pszenice antyku $i$ Bizancjum, s. 69; ciż, Wheats of Antiquity and Byzantium, s. 71.

${ }^{190} \mathrm{Na}$ jego temat Galen miał niewiele do powiedzenia, por. Kokoszko - Jagusiak, Pszenice antyku i Bizancjum, s. 65; ciż, Wheats of Antiquity and Byzantium, s. 67.

${ }^{191}$ Por. Galenus, De alimentorum facultatibus 482, 9-10.

${ }^{192}$ Por. tamże 480, 13 - 490, 8.

${ }^{193}$ Patrz niżej.

${ }^{194}$ Por. Galenus, De alimentorum facultatibus 486, 2.

${ }^{195}$ Por. tamże 486, 1.

${ }^{196}$ Por. tamże.

${ }^{197}$ Por. tamże 484, 6.

${ }^{198}$ Por. Kokoszko - Jagusiak, Pszenice antyku i Bizancjum, s. 65; ciż, Wheats of Antiquity and Byzantium, s. 68. 


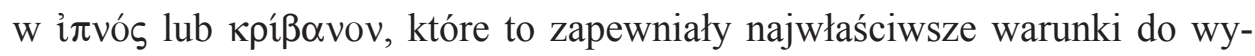
pieku bochenków. Jak pamiętamy, w stworzonej przez Galena klasyfikacji, w której za kryterium podziału chleba posłużyła technologia zastosowana do

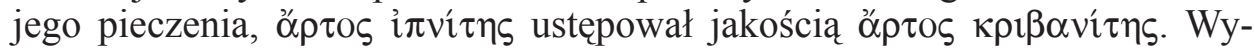
nikało to $z$ faktu, iż i $\pi v o$, choć zasadniczo pozwalały na udany wypiek, to jednak nie zapewniały tak dobrego jak к wnętrza ciasta. Skutkiem tego chleby typu i $\pi v i ́ \tau \alpha 1$, choć zasadniczo dietetycznie korzystne, mogły być niedopieczone w środku ${ }^{199}$. Z logiki wykładu wnioskujemy, że w i $\pi v o ́ \varsigma$ pieczono raczej kosztowniejsze gatunki chleba pszenne, białe, wyrabiane z dużą ilością zaczynu. W interpretacji Galena również $\kappa \rho ı \alpha v^{i} \tau \eta \varsigma$ był chlebem z ziarna pszennego. Można przypuszczać, że ten uznany przez lekarza za najlepszy sposób wypieku wydobywał z pszenicy

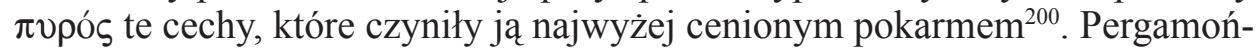

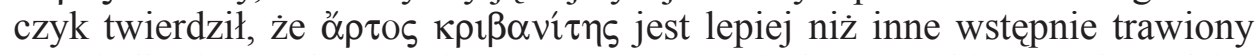
w żołądku i po zakończeniu tego procesu posiada wszystkie pożądane działania, jakich oczekujemy od pokarmu ${ }^{201}$. Stąd doskonale służy zdrowiu osób starszych $^{202}$ i w średnim wieku ${ }^{203}$.

Decydującym czynnikiem w naszych ustaleniach dotyczących chleba, jaki mógł mieć na myśli Klemens, będzie rodzaj mąki użytej do jego wypieku. To właśnie ona, nadmiernie przesiana - a więc, jak podejrzewamy, wyjątkowo biała - miała, według Aleksandryjczyka, czynić to pieczywo produktem nieodpowiednim dla chrześcijan: pozbawionym wartości odżywczych, luksusowym i prowadzącym do zniewieścienia. Do wyboru mamy dwa gatunki:

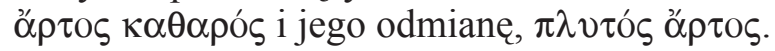

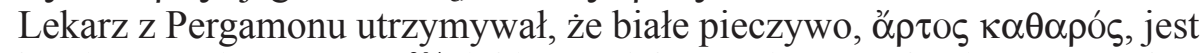
pozbawione zanieczyszczeń ${ }^{204}$, jakie mogłaby zawierać mąka, i ma stosunkowo duży ciężar przy niezbyt wielkiej objętości ${ }^{205}$. Ciasto, z którego jest wypiekane, powinno być lepkie oraz ciagłe $(\gamma \lambda \hat{\imath} \sigma \chi \rho \circ)^{206}$, tak aby nie rozrywało się w czasie rozciagania. Galen nie pisał tego wprost, ale owo $\gamma \lambda i ́ \sigma \chi \rho o v$ decydowało o zdolności masy do wyrastania, a po wypieku determinowało pulchność

${ }^{199}$ Por. Galenus, De alimentorum facultatibus 489, 10-12; zob. też: tenże, De victu attenuante 32, 7.

${ }^{200}$ Por. tenże, De alimentorum facultatibus 484, 5 - 485, 3.

${ }^{201}$ Por. tamże 484, 13 - 485, 2.

${ }^{202}$ Por. tamże 486, 1.

${ }^{203}$ Por. tamże 486, 1. Zauważmy, że pierwszeństwo dietetyczne tego gatunku pieczywa zostało przez Galena oświadczone nie tylko w De alimenotrum facultatibus, ale i w De victu attenunate $(32,7)$.

${ }^{204} \mathrm{Nie}$ ma zanieczyszczeń, ponieważ powstało z dobrze oczyszczonego ő $\lambda \varepsilon v \rho o v$. Zatem musiało być białe. $Z$ tekstu wynika również, że im jaśniejszy był chleb, tym wyżej go ceniono. Por. Jasny, The Daily Bread, s. 245, który ocenia, że w Efezie pieczywo to było wypiekane z mąki, do produkcji której wykorzystywano ok. $90 \%$ poddanego mieleniu surowca. Zob też: tenże, The Breads of Ephesus and Their Prices, „Agricultural History” 21 (1947) fasc. 3, 190-191.

${ }^{205}$ Por. Galenus, De alimentorum facultatibus 482, 5-6.

${ }^{206}$ Por. tamże 482, 7. Ta cecha była skutkiem obecności w nim glutenu. 
pieczywa. Uzyskanie idealnego ciasta wymagało użycia znacznej ilości drożdży, czy też zaczynu ${ }^{207}$, długiego procesu wyrabiania ${ }^{208}$ i znacznego czasu wypiekania $^{209}$. Rzymianie, podobnie jak i inne ludy, nazywali najczystszy chleb

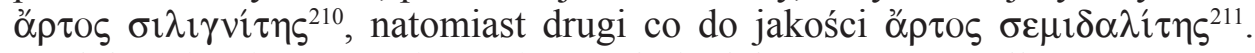
Medyk wyjaśnia, że termin $\sigma \varepsilon \mu i \delta \alpha \lambda \imath \iota \varsigma$ był od dawna znany Hellenom, w przeciwieństwie do nazwy oı $\lambda i \gamma v \imath \varsigma^{212}$. Przyznaje, że sam używa tego drugiego jako terminu technicznego, ponieważ nie znalazł zastępczego o bardziej helleńskim rodowodzie ${ }^{213}$. Według autora De alimentorum facultatibus, $\kappa \alpha \theta \alpha \rho o \grave{~}$

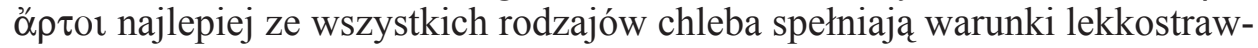
ności ${ }^{214}$, a więc, przypominamy, mają najwięcej zaczynu ${ }^{215}$, są dobrze wyro-

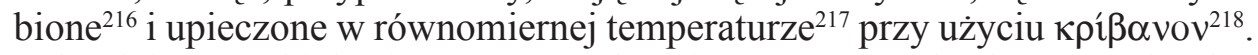
$\mathrm{Z}$ drugiej strony, białe pieczywo przechodzi przez przewód pokarmowy bardzo wolno, najoporniej ze wszystkich rodzajów chleba ${ }^{219}$. Daje jednak organizmowi, co istotne dla naszych rozważań, najwięcej pokarmu - najpożywniejszy jest $\alpha$ $\rho \tau o \varsigma ~ \kappa \alpha \theta \alpha \rho o ́ \varsigma ~ t y p u ~ \sigma i \lambda \imath \gamma v i ́ \tau \eta \varsigma^{220}$, potem zaś $\sigma \varepsilon \mu t \delta \alpha \lambda i \tau \eta \varsigma^{221}$. Wysoką

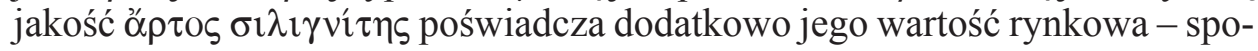
śród czterech gatunków chleba sprzedawanych w Efezie na przełomie I i II w., których ceny utrwaliły źródła, ten był najdroższy ${ }^{222}$.

O lekkim / płukanym chlebie Galen pisał w osobnym rozdziale De ali-

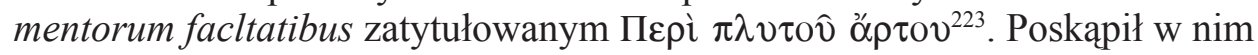
jednak informacji na temat sposobu przygotowywania tego pieczywa. Dowiadujemy się jedynie, że produkowano je z ở $\lambda \varepsilon v \rho v^{224}$. Sugestia dotycząca

${ }^{207}$ Por. tamże $482,9$.

${ }^{208}$ Por. tamże 482, 10. Podobne informacje na temat chleba Galen włączył także do rozdziału Пврi i $\tau p i ́ \omega v$, por. tamże 492, 3 - 494, 8.

${ }^{209}$ Por. tamże 482, 10.

${ }^{210}$ Por. tamże 483, 13-15.

${ }^{211}$ Por. tamże 483, 15.

${ }^{212}$ Por. tamże 483, 15-16.

${ }^{213}$ Por. tamże 483, 16-17.

${ }^{214}$ Por. tamże 484, 6 .

${ }^{215}$ Por. tamże 484, 6.

${ }^{216}$ Por. tamże 484, 7.

${ }^{217}$ Por. tamże 484, 7.

${ }^{218}$ Por. tamże $484,8$.

${ }^{219}$ Por. tamże 482, 6-7.

${ }^{220}$ Por. tamże 484, 1.

${ }^{221}$ Por. tamże 484, 2.

${ }^{222}$ Kosztował trzy obole za bochenek, który był jednym z najlżejszych ze wszystkich wycenianych, por. Jasny, The Breads of Ephesus, s. 190-191.

${ }^{223}$ Por. Galenus, De alimentorum facultatibus 494, 9 - 496, 2.

${ }^{224}$ Por. tamże 494, 16. 
niezwykle małego ciężaru chleba ${ }^{225}$ wskazuje, że był dobrze wyrośnięty ${ }^{226}$. Zapewne, by rósł jak najlepiej, wypiekano go jedynie z dokładnie oczyszczonej, wysokoglutenowej mąki, a ciasto wyrabiano długo, z dużą ilością zakwasu. Najprawdopodobniej pieczono go w крíßavov, co pozwalało na uzy-

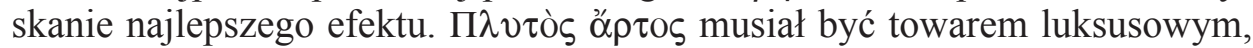
spożywanym przez nielicznych, przy wyjątkowych okazjach. Oprócz wyżej wspomnianych cech, świadczyła o tym - zaakcentujmy to wyraźnie - jego bardzo mała wartość odżywcza ${ }^{227}$. Nie jadano go więc po to, by wzmocnić siły organizmu. Jednocześnie posiadał on, według Galena, wiele pożądanych cech dietetycznych. Nie powodował, m.in. blokady pracy organów wewnętrznych $^{228}$, a to za sprawą tego, iż nie był ani gęsty ${ }^{229}$, ani kleisty ${ }^{230}$, a jego właściwości zmieniały się z ziemistych ${ }^{231}$ na powietrzne ${ }^{232}$. Jego lekkostrawność potwierdza niewielki ciężar; miał nie tonąć w wodzie, ale utrzymywać się na

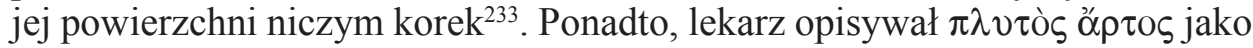
pokarm o właściwościach pośrednich między rozgrzewającymi $(\theta \varepsilon \rho \mu \alpha i ́ v o v-$ $\tau \alpha)$ a chłodzącymi $(\psi v ́ \chi 0 \nu \tau \alpha)^{234}$.

Dla porównania z gatunkami przygotowywanymi z najlepszej gatunkowo, dobrze przesianej mąki, zapoznajmy się z opinią Galena dotyczącą chlebów z drugiego krańca skali, a więc takich, które zawierały otręby. Są to: umiesz-

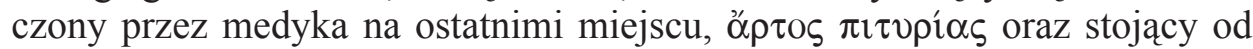

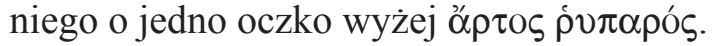

Galen thumaczy, że białe ziarna pszeniczne ${ }^{235}$, cechujące się wewnętrzną niespójnością ${ }^{236}$, po zmieleniu dają stosunkowo dużą ilość otrąb ( $\left.\pi^{\prime} i \tau \rho \rho v\right)^{237}$. To one, gdy odsieje się je ${ }^{238}$ od zasadniczej masy mąki ő $\lambda \varepsilon v \rho o v^{239}$, wciąż jednak przemieszane z jej resztkami, stają się podstawą do wypieku ó $\rho \tau o \varsigma ~ \pi l-$ $\tau v i^{\prime} \alpha \varsigma^{240}$. Produkcja tego typu pieczywa nie wymagała zbyt wiele wysiłku od przygotowującej je osoby. Ilość drożdży mogła być niewielka ${ }^{241}$, a czas

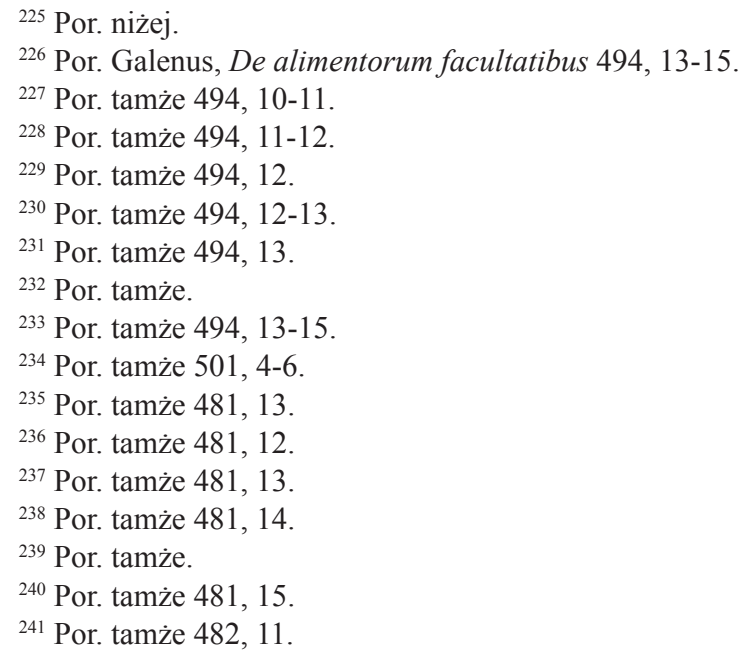


niezbyt energicznego wyrabiania, podobnie zresztą jak i okres wypieku ${ }^{242}$, nie musiał być długi ${ }^{243}$. Medyk oceniał, iż chleb ten nie jest zbyt pożywny ${ }^{244}$, a $\mathrm{w}$ przewodzie pokarmowym pozostawia wiele elementów nietrawionych $\left(\pi \varepsilon \rho^{i} \tau \tau \omega \mu \alpha\right)^{245}$. Za sprawą cech samych otrąb, przechodzi jednak szybko przez ten układ ${ }^{246}$. Tę ostatnią zdolność posiadają bowiem same $\pi i ́ \tau v \rho \alpha^{247}$,

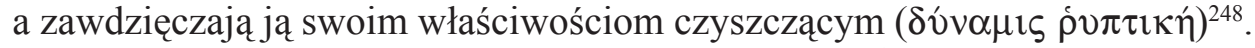
Tym samym pobudzają też wnętrzności do wydalania ${ }^{249}$, a zatem wypiek z ich zawartością możemy uznać za zdrowy dla organizmu.

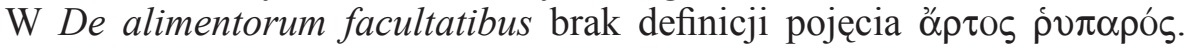

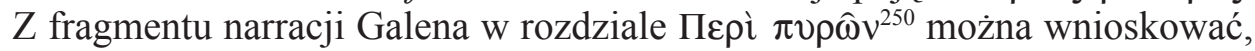
że jest to chleb pszeniczny o wysokiej zawartości otrąb. Nazwa ${ }^{251}$ wskazuje też na ciemne zabarwienie tych wypieków; z pewnością były one ciemniej-

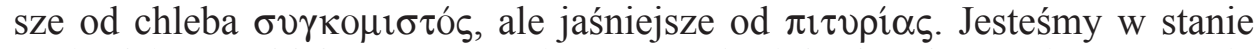
stwierdzić, że chleb tego typu nie wymagał wiele drożdży, a ciasto nań nie potrzebowało długiego wyrabiania. Bochenki pieczono stosunkowo krótko,

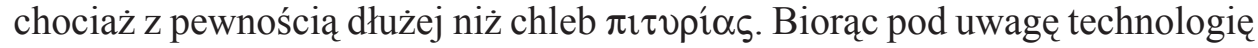
wypieku, trudno podejrzewać, by to niezbyt wartościowe pieczywo - zarówno pod względem jego cech dietetyczno-kulinarnych, jak i z uwagi na wartość

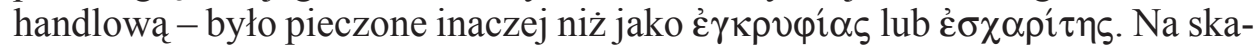
li pożywności zajmowało jedno z ostatnich miejsc ${ }^{252}$; jedynie ő $\rho \tau o \varsigma ~ \pi \imath \tau v \rho i ́ \alpha \varsigma$ był od niego pod tym względem gorszy. Z uwagi na fakt, iż zawierał znaczną

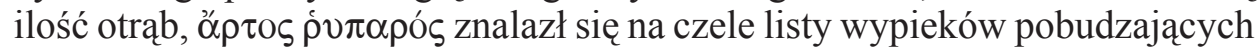
pracę jelit ${ }^{253} \mathrm{i}$ - skutkiem tego - musiał zajmować drugie, tuż po $\pi \imath \tau v \rho i ́ \alpha \varsigma$, miejsce w rankingu chlebów, które szybko przechodzą przez przewód pokarmowy ${ }^{254}$. Tym samym i on, jako wzmagający perystaltykę jelit, uznany zostać może za zdrowy produkt spożywczy.

Do omówienia pozostał nam chleb zajmujący centralną pozycję w wykazie pieczywa ocenianego ze względu na użytą do wypieku mąkę. Jest to wypiek

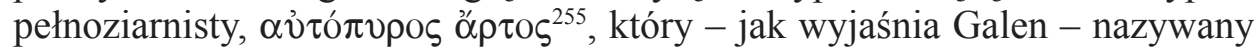

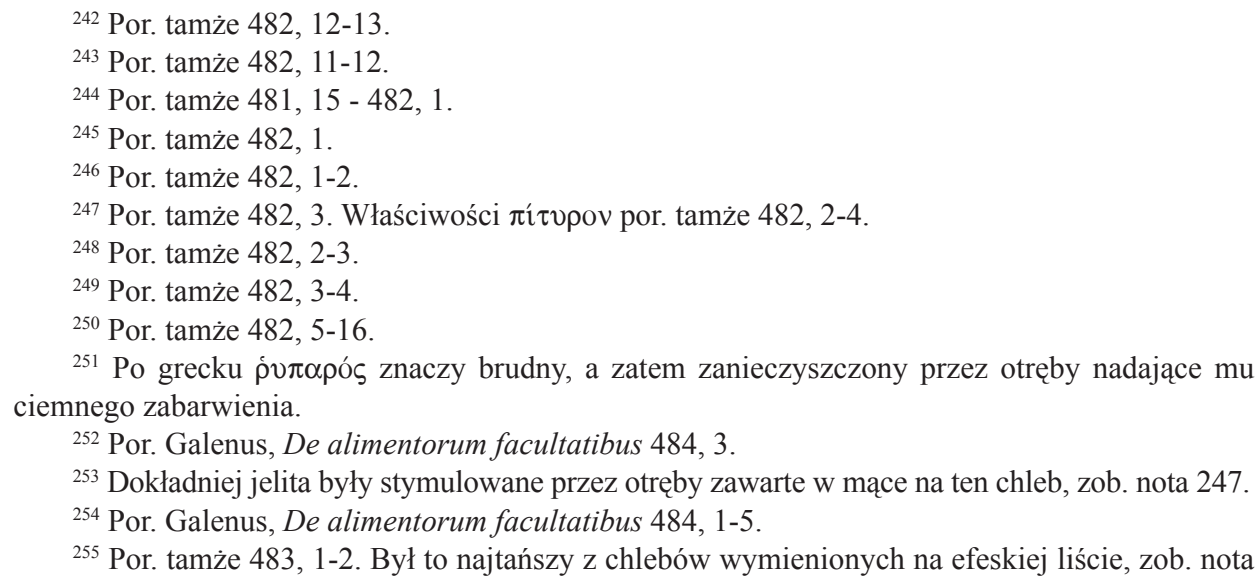

${ }^{252}$ Por. Galenus, De alimentorum facultatibus 484, 3.

${ }^{253}$ Dokładniej jelita były stymulowane przez otręby zawarte w mące na ten chleb, zob. nota 247.

${ }^{254}$ Por. Galenus, De alimentorum facultatibus 484, 1-5.

${ }^{255}$ Por. tamże 483, 1-2. Był to najtańszy z chlebów wymienionych na efeskiej liście, zob. nota 


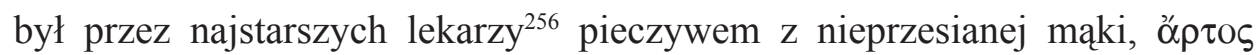

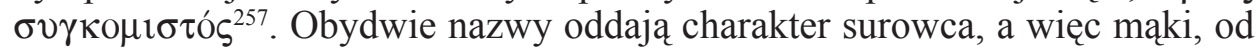
której nie oddzielono otrą ${ }^{258} \mathrm{i}$ która zawiera w sobie dokładnie wszystkie części ziarna zmielonego na ớ $\lambda \varepsilon v \rho v^{259}$. Z narracji Galena wynika, iż w ocenie

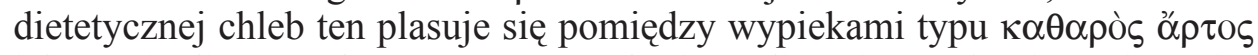

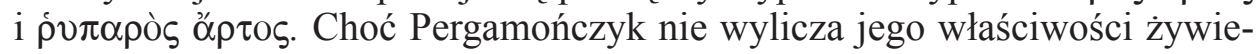
niowych, to zaznacza, że poszczególne typy tego pieczywa mogą się od siebie pod tym względem różnić, w zależności od cech samej pszenicy użytej do

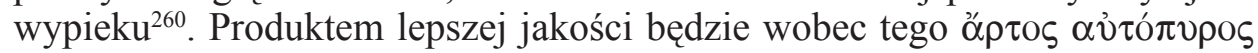
z ciężkiego ziarna o zwartej konsystencji ${ }^{261}$, podczas gdy lekka pszenica o luźnej strukturze wewnętrznej da gorszy wyrób ${ }^{262}$.

W medycznych pismach Galena znajdujemy potwierdzenie słów Klemensa Aleksandryjskiego, mówiących, że na przełomie II i III w. chleb stanowił podstawowy produkt spożywczy. Ten najwartościowszy - zdaniem lekarza wypiekany był z pszenicy $\pi$ vó́s. Odpowiedni surowiec i sposób jego obróbki - dokładne zmielenie ziarna i przesianie mąki, staranne wyrobienie ciasta, do którego dodano drożdży lub zaczynu, i pieczenie masy w równomiernej temperaturze bez bezpośredniego kontaktu z popiołem - zapewniały wypiekowi zyskanie najlepszych własności. Taki pokarm został przez medyka oceniony jako wyjątkowo zdrowy, nadający się do zastosowania w wielu dietach i właściwy do wykorzystywania jako medykament. Spełnienie wszystkich wspomnianych warunków było jednak kosztowne i nie mogło obyć się bez dużego nakładu czasu i pracy. $Z$ reguły mieszkańcy wsi nie byli w stanie sprostać tym wysokim wymogom, zatem, jak podaje Galen, chleb pszenny jedzony był przede wszystkim w miastach.

Pergamończyk wylicza i charakteryzuje kilka gatunków pieczywa wytwarzanego z pszenicy. Pod względem kulinarnym i dietetycznym ich rankingi przedstawiają się u niego identycznie. Za wypiek luksusowy - zdaniem Klemensa nie-

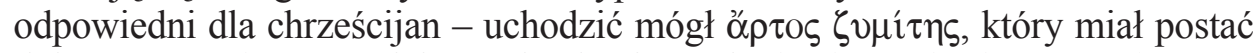
dobrze wyrośniętego, pulchnego bochenka. Jedynie pieczenie ciasta w кṕ́ß $\alpha$ vov, ewentualnie w i $\pi v o ́ s$, zapewniało mu jednakową temperaturę przez cały czas

222. Skoro jednak zajmuje na niej drugie miejsce, N. Jasny (The Breads of Ephesus, s. 190) nie uważa go za powszechne pieczywo pszenne sprzedawane na rynku.

${ }^{256}$ Por. Galenus, De alimentorum facultatibus 483, 2-3.

${ }^{257}$ Por. tamże 483, 2.

${ }^{258}$ Por. tamże 483, 3-4.

${ }^{259}$ Por. tamże 483, 4-5.

${ }^{260}$ Por. tamże 483, 8-10.

${ }^{261}$ Por. tamże 483, 10-11.

${ }^{262}$ Por. tamże 483, 11-12. 
trwania tego procesu i gwarantowało równomierny wypiek, bez spalonej skórki czy surowego środka. Wymienione naczynia chroniły też produkt przed mogącym go zanieczyścić od zewnątrz popiołem. Wobec tego to któreś z nich musiało być użyte dla uzyskania wypieku godnego uznania za wykwintny.

Dokładnie przesiana mąka, o której czytamy u Aleksandryjczyka, wskazu-

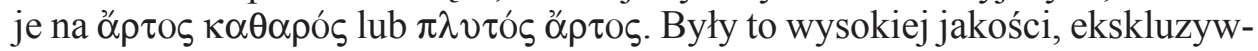
ne wyroby. Z uwagi na cechy dietetyczne, nasz medyk podaje ich liczne zale-

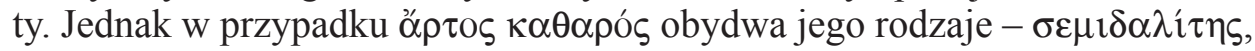
a tym bardziej $\sigma \imath \lambda \iota \gamma v i ́ \tau \eta s-w$ opinii Galena uchodzą za wyjątkowo pożywne. To nie pozwala identyfikować ich z chlebem skrytykowanym przez Klemensa w Wychowawcy. Zupełnie inaczej w szacunkach medyka wygląda pożywność

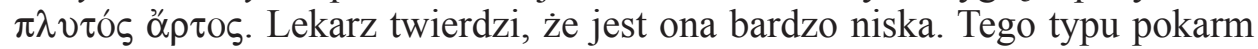
nie wzmacniał więc organizmu, przeciwnie osłabiał go, czy też, posługując się określeniem Aleksandryjskiego Scholarchy, powodował jego zniewieścienie. Na zakup lub przyrządzenie tego pieczywa pozwolić sobie mogli jedynie ludzie zamożni. Powyższe ustalenia pozwalają nam twierdzić, że spośród wszystkich rodzajów chleba poddanych analizie przez Galena, temu, o jakim

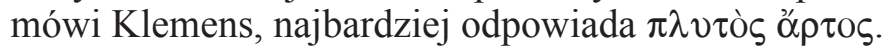

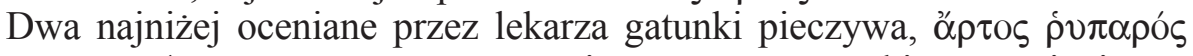

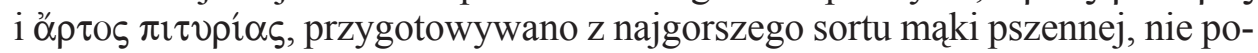
święcając tej czynności zbyt wiele czasu czy wysiłku, nie korzystając z najlepiej nadających się do pieczenia naczyń. W efekcie uzyskiwano nie tyle bochenki, co płaskie, niewyrośnięte placki, którym zawarte w nich otręby nadawały ciemną barwę. $Z$ pewnością ich konsumentami byli ludzie biedni i niewolnicy. Galen, choć zaznacza, że wypieki te dobrze wpływają na perystaltykę jelit, ogólnie negatywnie ocenia ich dietetyczne własności. Jedną z ich wad była stosunkowo mała pożywność. Sformułowana przez Pergamończyka doktryna głosi, że wraz ze wzrostem zawartości otrąb w mące, spada wartość odżywcza uzyskiwanego z niej chleba. Stąd, by wzmocnić siły organizmu, należy żywić

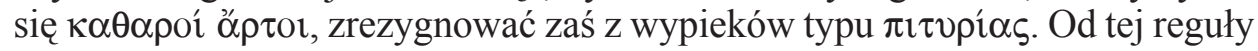

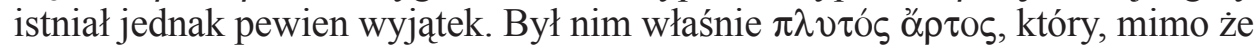
wykonany z bardzo dobrze oczyszczonego surowca, uchodził w opinii Galena za pożywny jedynie w niewielkim stopniu ${ }^{263}$. Klemens Aleksandryjski swoją wypowiedzią o pozbawianiu mąki wartości odżywczych przez jej nadmierne przesiewanie wykazuje się znajomością powyższej teorii dietetycznej. Nie dysponujemy pewnymi dowodami na to, by czytał on Galenowe traktaty, choć wydaje się to możliwe. Jednak nawet jeśli twórczość medyka była mu obca, to - jak wiemy - chętnie czerpał z wiedzy wielu starożytnych uczonych żyjących w poprzedzających go czasach. Współczesne badania ${ }^{264}$ ukazują ciągłość antycznych doktryn żywieniowych na przestrzeni wieków, zatem Scholarcha

${ }^{263}$ Por. Kokoszko - Jagusiak, Pszenice antyku i Bizancjum, s. 84, nota 348.

${ }^{264} \mathrm{~Np}$. cytowane w tym tekście kilkakrotnie: Kokoszko - Jagusiak - Rzeźnicka, Dietetyka 
mógł poznać opinie innych lekarzy na temat chleba i na ich podstawie formułować w Wychowawcy swoje krytyczne sądy dotyczące jednego z jego gatunków.

Jakie pieczywo było zatem w tamtych czasach godne polecenia? Galen promuje zajmujący centralne miejsce w jego klasyfikacji o̊p uznając go zarówno za zdrowy, jak i pożywny. Czy również Klemens rekomendowałby go chrześcijanom, do których kierował swoje słowa? Biorąc pod uwagę jego stosunek do dóbr materialnych, możemy przyjąć, że byłby to i jego wybór. Scholarcha odrzucał zbytek, ale cenił zdrowie, stąd skrajny ascetyzm dotyczący żywności, jaki w nieco późniejszych czasach praktykowali mnisi ${ }^{265}$, byłby mu zapewne obcy.

\section{BREAD UNFIT FOR THE CHRISTIANS: \\ MORAL RECOMMENDATIONS OF CLEMENT OF ALEXANDRIA CONFRONTING SCHOLARLY DOCTRINES OF GALEN}

\section{(Summary)}

The goal of the present discussion is to determine what kind of bread Clement of Alexandria had in mind, when, in his Paedagogus, castigated some of Alexandria inhabitants for the consumption of a kind produced form excessively purified (by sieving) flour (which due to the process was becoming devoid of any nutritional values), which, as an item of luxury, would ultimately lead its consumers to effeminacy.

In order to identify the food and link it to the varieties produced in those times, the authors of the study have analyzed select treatises of Galen, who, being a contemporary of Clemens, is acclaimed to have been the most eminent physician of the period between the IInd and the IIIrd centuries after Christ, and an authority in the area of bread nutritional values.

Having outlined the scope of Clement's activities and knowledge as well as having presented the corpus of data in the line left by Galen, the authors of the present study conclude, that the Christian wrote about a kind of bread baked with a generous amount of leaven (since it was the additive that made the dough rise),

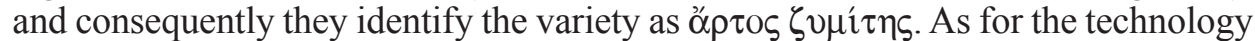
of baking, they opine that the bread described by the Christin writer belonged to bread types obtained from $\kappa \rho i \beta \alpha v o v$ or i $\pi v o ́ \varsigma$ ovens. The authors also opine that the crucial piece of information given by Clement allowing to identify the variety is the

i sztuka kulinarna, cz. 1, czy Cereals of Antiquity and Early Byzantine Times i inne prace tych autorów poświęcone podobnej tematyce.

${ }^{265}$ Syryjscy mnisi, o których opowiada Teodoret z Cyru, spożywali nisko ceniony przez medyków, mało odżywczy i mało wykwintny chleb jęczmienny, por. M. Kokoszko - J. Dybała - K. Jagusiak - Z. Rzeźnicka, Dieta mnichów syryjskich. Komentarz do terminu artos kachrydias (óp

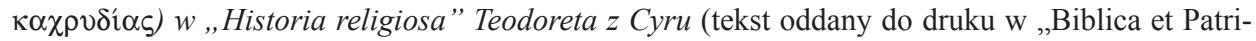
stica Thoruniensia"). 
one concerning flour used for the purpose. They claim that, since it was presented as very well-sieved, contributing to the whiteness of the bread and consequently to its classification as luxurious, the choice is limited to two kinds of the food, namely

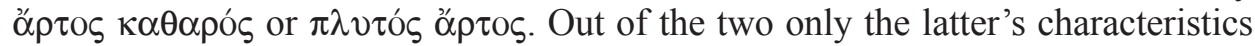
given by Galen matche Clement's description of the bread as a foodstuff of low nutritional value. Consequently, the authors of the article conclude that it was $\pi \lambda v \tau$ ì $\varsigma$

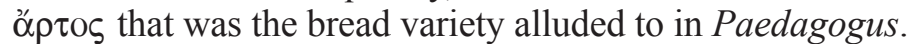

Moreover, they come to the opinion that the discussion on bread show that Clement's words included in Paedagogus show consistency with contemporary dietetic doctrines. Accordingly, the latter were either not absent from the Christian's general knowledge or constructed on popular lore he shared.

Key words: Clement of Alexandria, Galen, wheat, wheat bread, ancient gastronomy, ancient dietetics.

Słowa kluczowe: Klemens Aleksandryjki, Galen, pszenica, chleb pszenny, antyczna gastronomia, antyczna dietetyka.

\section{BIBLIOGRAFIA:}

\section{Źródła}

Clemens Alexandrinus, Paedagogus I: ed. H.I. Marrou - M. Harl, SCh 70, Paris 1960, II: ed. C. Mondésert - H.I. Marrou, SCh 108, Paris 1965, II: ed. C. Mondésert - C. Matray - H.I. Marrou, SCh 158, Paris 1970, tłum. M. Szarmach: Klemens Aleksandryjski, Wychowawca, Torun 2012.

Galenus, De alimentorum facultatibus, ed. D.C.G. Kühn, w: Claudii Galeni Opera omnia, vol. 6, Lipsiae 1823.

Galenus, De compositione medicamentorum secundum locos libri X, ed. C.G. Kühn, w: Claudii Galeni Opera omnia, vol. 12, Lipsiae 1826, 378-1007, vol. 13, Lipsiae $1827,1-361$.

Galenus, De simplicium medicamentorum temperamentis ac facultatibus libri XI, ed.

C.G. Kühn, w: Claudii Galeni Opera omnia, vol. 11, Lipsiae 1826, 379-892; vol. 12, Lipsiae 1827, 1-377.

Galenus, De victu attenuante, ed. K. Kalbfleisch, Leipzig - Berlin 1923.

Galenus, In Hippocratis de victu acutorum commentaria libri IV, ed. I. Mewaldt G. Helmreich - I. Westenberger, w: Galeni In Hippocratis de natura hominis, In Hippocratis de victu acutorum, De diaeta Hippocratis, In morbis acutis, Lipsiae - Berolini 1914, 115-366.

\section{Opracowania}

Alcock J.P., Food in Roman Britain, Stroud 2001.

Alcock J.P., Food in the Ancient World, Westport - London 2006.

Altaner B. - Stuiber B., Patrologia, tłum. P. Pachciarek, Warszawa 1990.

Amouretti M.-C., Urban and Rural Diets in Greece, w: Food. A Culinary History from Antiquity to the Present, ed. J.-L. Flandrin - M. Montanari; Eng. ed. A. Sonnenfeld, New York - Chichester 1999, 79-89.

Arikha N., Passions and Tempers. A History of the Humours, New York 2007. 
Balter M., Seeking Agriculture’s Ancient Roots, „Science” (2007) vol. 316, 1830-1835.

BARKer G., Prehistoric Farming in Europe, Cambridge 1985.

Bartlett B., How Excessive Government Killed Ancient Rome, „Cato Journal” 14 (1994) fasc. 2, 287-303.

Bar-Yosef O. - Meadow R.H., The Origins of Agriculture in the Near East, w: Last Hunters, First Farmers. New Perspectives on the Prehistoric Transition to Agriculture. Seminar. Papers, ed. T.D. Price - A.B. Gebauer, Santa Fe 1995, 39-94.

Bar-Yosef O., The Natufian Culture in the Levant, Threshold to the Origins of Agriculture, „Evolutionary Anthropology” 6 (1998) fasc. 5, 159-177.

BednARCzyK A., Galen. Główne kategorie systemu filozoficzno-lekarskiego, Warszawa 1995.

Bober Ph.P., Art, Culture, and Cuisine. Ancient and Medieval Gastronomy, Chicago London 1999.

Borowski O., Eat, Drink and Be Merry. The Mediterranean Diet, „Near Eastern Archaeology" 67 (2004) fasc. 2, 96-107.

Bos J., The Rise and Decline of Character. Humoral Psychology in Ancient and Early Modern Medical Theory, „History of the Human Sciences” 22 (2009) fasc. 3, 29-50.

Boulos L. - Fahmy A.G., Grasses in Ancient Egypt, „Kew Bulletin” 62 (2007) fasc. 3, 507-511.

Bowen E.W., Roman Commerce in the Early Empire, „The Classical Weekly” 21 (1928) 201-206.

CAmPenhausen von H., Ojcowie Kościoła, tłum. K. Wierszyłowski, Warszawa 1998.

CAsson L., Maritime Trade in Antiquity, „Archaeology” 34 (1981) fasc. 4, 37-43.

CAsson L., The Role of the State in Rome's Grain Trade, „Memoirs of the American Academy in Rome" 36 (1980) 21-33.

CHADwick H., Myśl wczesnochrześcijańska a tradycja klasyczna, tłum. P. Siejkowski, Poznań 2000.

Civitello L., Cuisine and Culture. A History of Food and People, ed., Hoboken - Chichester 2008.

Cool H.E.M., Eating and Drinking in Roman Britain, Cambridge 2006.

CurTis R.I., Ancient Food Technology, Leiden - Boston - Köln 2001.

Czarnuch M., Clement of Alexandria's Attitude towards the Greek Philosophy, „Scripta Classica" 10 (2013) 141-146.

Czyżewski B., ,Idź, sprzedaj, co posiadasz, i rozdaj ubogim, a będziesz miat skarb w niebie”. (Mt 19,21) w egzegezie Ojców Kościoła, TPatr 10 (2013) 33-42.

Dalby A. - Grainger S., The Classical Cookbook, London 1996.

Dalby A., Food in the Ancient World from A to Z, London - New York 2003.

Dalby A., Siren Feasts. A History of Food and Gastronomy in Greece, London 1996.

DARMEZIN L., L'approvisionnement en blé des cités grecques à l'époque hellénistique, $\mathrm{w}$ : Rites et rythmes agraires. Séminaire de recherche sous la direction de Marie-Claire Cauvin, Lyon 1991, 113-118.

Davies R.W., The Roman Military Diet, „Britannia” 2 (1971) 122-142.

De Angelis F., Going against the Grain in Sicilian Greek Economics, „Graece and Rome” 53 (2006) fasc. 1, 29-47.

De Wet J.M.J., Grasses and the Culture History of Man, „Annals of the Missouri Botanical Garden" 68 (1981) fasc. 1, 87-104.

Desjardins M., Clement's Bound Body, w: Mapping Gender in Ancient Religious Discourses, ed. T. Penner - C. Vander Stichele, Leiden - Biggleswade 2006, 411-430. 
Diamond J.M., Strzelby, zarazki, maszyny. Losy ludzkich społeczeństw, tłum. M. Konarzewski, Warszawa 2012.

Donahue J.R., Stoic Indifferents and Christian Indifference in Clement of Alexandria, „Traditio” 19 (1963) 438-446.

DrączKowski F., Eklezjologia Klemensa Aleksandryjskiego, w: Kościół starożytny - Królestwo Chrystusa i instytucja, red. F. Drączkowski i in., Lublin 2010, 51-75.

Drączkowski F., Klemens Aleksandryjski, EK IX 98-102.

ERdKAmp P., The Corn Supply of the Roman Armies during the Third and Second Centuries B.C., „Historia” 44 (1995) fasc. 2, 168-191.

Erdkamp P., The Grain Market in the Roman Empire. A Social, Political and Economic Study, Cambridge 2005.

Evans J.K., Wheat Production and Its Social Consequences in the Roman World, CQ 31 (1981) fasc. 2, 428-442.

Fernandez-Armesto F., Near a Thousand Tables. A History of Food, New York 2002.

FIELD H., Ancient Wheat and Barley from Kish, Mesopotamia, „American Anthropologist” 34 (1932) fasc. 2, 303-309.

Forstner D., Świat symboliki chrześcijańskiej, przekł. i oprac. W. Zakrzewska - P. Pachciarek - R. Turzyński, Warszawa 1990.

Garnsey P., Famine and Food Supply in the Graeco-Roman World. Responses to Risk and Crisis, Cambridge 1989.

Garnsey P., Food and Society in Classical Antiquity, Cambridge 1999.

Garrard A. - Colledge S. - Martin L., The Emergence of Crop Cultivation and Caprine Herding in the „Marginal Zone” of the Southern Levant, w: The Origins and Spread of Agriculture and Pastoralism in Eurasia, ed. D.R. Harris, London 1996, 204-226.

Gourevitch D., Le pain des Romains à l'apogée de l'Empire. Bilan entomo- et botano-archéologique, „Comptes rendus des séances de l'Académie des Inscriptions et Belles-Lettres" 149 (2005) fasc. 1, 27-47.

Graham D.W., Diogenēs of Apollōnia, w: The Encyclopedia of Ancient Natural Scientists. The Greek Tradition and its Many Heirs, ed. P. Keyser - G.L. Irby-Massie, Milton Park - New York 2008, 252.

Grant M., Introduction, w: Galen, On Food and Diet, transl. M. Grant, London 2000, $1-13$.

Grimm V., The Good Things that Lay at Hand. Tastes of Ancient Greece and Rome, w: Food. The History of Taste, ed. P. Freedman, Berkeley 2007, 63-98.

HaAs Ch., Alexandria in Late Antiquity. Topography and Social Conflict, Baltimore London 1997.

Halstead P., The Development of Agriculture and Pastoralism in Greece. When, How, Who and What?, w: The Origins and Spread of Agriculture and Pastoralism in Eurasia, ed. D.R. Harris, London 1996, 296-309.

Hankinson R.J., Galen of Pergamon, w: The Encyclopedia of Ancient Natural Scientists. The Greek Tradition and its Many Heirs, ed. P. Keyser - G.L. Irby-Massie, Milton Park -New York 2008, 335-339.

Hankinson R.J., The Man and His Work, w: The Cambridge Companion to Galen, ed. R.J. Hankinson, Cambridge - New York 2008, 1-33.

Harcum C.G., A Study of Dietetics among the Romans (Concluded), „The Classical Weekly” 12 (1918) fasc. 9, 66-68.

Harlan J.R., The Origins of Cereal Agriculture in the Old World, w: Origins of Agriculture, ed. Ch.A. Reed, Hague 1977, 357-383. 
Havrda M., Galenus Christianus? The Doctrine of Demonstration in Stromata VIII and the Question of its Source, VigCh 65 (2011) 343-375.

Helbaex H., Late Bronze Age and Byzantine Crops at Beycesultan in Anatolia, „Anatolian Studies" 11 (1961) 77-97.

Heszen A., „Paideia” Klemensa Aleksandryjskiego na przykładzie jego „Hymnu do Chrystusa Zbawiciela”, „Symbolae Philologorum Posnaniensium Graecae et Latinae" 19 (2009) 121-134.

Horstmanshoff H.F.J., Galen and His Patients, w: Ancient Medicine in its Socio-Cultural Context. Papers Read at the Congress Held at Leiden University, 13-15 April 1992, vol. 1, ed. Ph. J. van der Eijk - H.F.J. Horstmanshoff - P.H. Schrijvers, Amsterdam Atlanta 1995, 83-99.

JAEGER W., Wczesne chrześcijaństwo i grecka Paideia, thum. K. Bielawski, Bydgoszcz 2001.

Jagusiak K. - Koкoszko M., Pisma Orybazjusza jako źródło informacji o pożywieniu ludzi w późnym Cesarstwie Rzymskim, VoxP 33 (2013) t. 59, 339-357.

JAGUSiaK K. - KокоSzko M., Życie i kariera Orybazjusza w świetle relacji źródłowych, „Przegląd Nauk Historycznych” 10 (2011) fasc. 1, 5-21.

JaSny N., Competition Among Grains in Classical Antiquity, „The American Historical Review" 47 (1942) fasc. 4, 747-764.

JASNy N., The Breads of Ephesus and Their Prices, „Agricultural History” 21 (1947) fasc. 3, 190-192.

JASNy N., The Daily Bread of the Ancient Greeks and Romans, „Osiris” 9 (1950) 227-253.

JASNy N., Wheat Prices and Milling Costs in Classical Rome, „Wheat Studies” 20 (1944) fasc. 4, 137-170.

Jones T.B., Ancient Mesopotamian Agriculture, „Agricultural History” 26 (1952) fasc. 2, 46-51.

Jounnna J., Hippokratēs of Khios, w: The Encyclopedia of Ancient Natural Scientists. The Greek Tradition and its Many Heirs, ed. P. Keyser - G.L. Irby-Massie, Milton Park New York 2008, 401-405.

Jounnna J., La théorie des quatre humeurs et des quatre tempéraments dans la tradition latine (Vindicien, Pseudo-Soranos) et une source grecque retrouvée, REG 118 (2005) fasc. 1, 138-167.

JundzIıt J., Czy człowiek bogaty może być zbawiony? Bogactwo i ubóstwo w świetle myśli patrystycznej, w: Patrystyczne dziedzictwo społecznej nauki Kościoła. VIII Bydgoskie Dni Społeczne (14-18 III 1994), red. T. Makowski, Gniezno 1996, 31-40.

Karavites P., Evil - Freedom - and the Road to Perfection in Clement of Alexandria, Leiden - Boston - Köln 1999.

Karczewski M., ,, Wszystko mieli wspólne” (Dz 2,44b). Pierwsi chrześcijanie wobec dóbr materialnych, „Forum Teologiczne” 7 (2006) 15-28.

Kaufman C.K., Cooking in Ancient Civilizations, Westport 2006.

Kessler D. - Temin P., The Organization of the Grain Trade in the Early Roman Empire, „The Economic History Review” 60 (2007) fasc. 2, 313-332.

Killgrove K. - Tykot R.H., Food for Rome. A Stable Isotope Investigation of Diet in the Imperial Period (1st-3rd centuries AD), „Journal of Anthropological Archaeology” 32 (2013) 28-38.

Klibengajtis T., „Nasiona prawdy” pogan. Poezja jako locus theologicus wedtug Klemensa z Aleksandrii, CT 73 (2003) fasc. 3, 61-76.

Kokoszko M. - Dybąa J. - Jagusiak K. - Rzeźnicka Z., Dieta mnichów syryjskich. Ko-

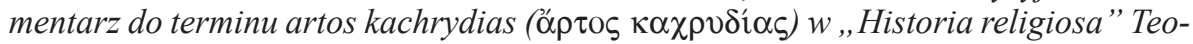
doreta z Cyru (oddany do druku w „Biblica et Patristica Thoruniensia”). 
Konoszko M. - Jagusiak K. - Rzeźnicka Z., Barley, w: ciż, Cereals of Antiquity and Early Byzantine Times. Wheat and Barley in Medical Sources (Second to Seventh Centuries AD), transl. K. Wodarczyk - M. Zakrzewski - M. Zytka, Łódź - Kraków 2014, 311-432.

Konoszko M. - Jagusiak K. - Rzeźnicka Z., Cereals of Antiquity and Early Byzantine Times. Wheat and Barley in Medical Sources (Second to Seventh Centuries AD), transl. K. Wodarczyk - M. Zakrzewski - M. Zytka, Łódź-Kraków 2014.

Koкoszko M. - Jagusiak K. - Rzeźnicka Z., Dietetyka i sztuka kulinarna antyku i wczesnego Bizancjum (II-VII w.), cz. 1: Zboża i produkty zbożowe $w$ źródłach medycznych antyku $i$ wczesnego Bizancjum, Łódź 2014.

Kokoszko M. - Jagusiak K. - Rzeźnicka Z., Jęczmień, w: M. Kokoszko - K. Jagusiak Z. Rzeźnicka, Dietetyka i sztuka kulinarna antyku i wczesnego Bizancjum (II-VII w.), cz. 1: Zboża i produkty zbożowe w źródłach medycznych antyku $i$ wczesnego Bizancjum, Łódź 2014, 311-438.

Kokoszko M. - Jagusiak K. - Rzeźnicka Z., Wstęp. Dietetyka, farmakologia i sztuka kulinarna w źródtach medycznych, w: Dietetyka i sztuka kulinarna antyku $i$ wczesnego Bizancjum (II-VII w.), cz. 2: Pokarm dla ciała i ducha, red. M. Kokoszko, Łódź 2014, $55-66$.

Koкоszko M. - Jagusiak K. - Rzeźnicka Z., Wstęp. Wiedza o pokarmach w źródłach medycznych. Dietetyka, farmakologia i sztuka kulinarna, w: M. Kokoszko - K. Jagusiak - Z. Rzeźnicka, Dietetyka i sztuka kulinarna antyku i wczesnego Bizancjum (II-VII .), cz. 1: Zboża i produkty zbożowe w źródłach medycznych antyku $i$ wczesnego Bizancjum, Łódź 2014, 5-26.

Kokoszko M. - Jagusiak K., Pszenice antyku i Bizancjum, w: M. Kokoszko - K. Jagusiak - Z. Rzeźnicka, Dietetyka i sztuka kulinarna antyku $i$ wczesnego Bizancjum (II-VII w.), cz. 1: Zboża i produkty zbożowe w źródtach medycznych antyku i wczesnego Bizancjum, Łódź 2014, 27-309.

Koкoszko M. - Jagusiak K., Wheats of Antiquity and Byzantium, w: M. Kokoszko - K. Jagusiak - Z. Rzeźnicka, Cereals of Antiquity and Early Byzantine Times. Wheat and Barley in Medical Sources (Second to Seventh Centuries AD), transl. K. Wodarczyk - M. Zakrzewski - M. Zytka, Łódź - Kraków 2014, 29-310.

Kokoszko M. - JaGusiaK K., Woda, wino i tak dalej, czyli o napojach i trunkach w Konstantynopolu, „Przegląd Nauk Historycznych” 9 (2010) fasc. 1, 25-54.

Kокоszko M. - JagusiaK K., Zboża Bizancjum. Kilka uwag na temat roli produktów zbożowych na podstawie źródet greckich, „Zeszyty Wiejskie” 17 (2012) 19-38.

Koкoszko M. - Rzeźnicka Z., Dietetyka $w$ „,De re coquinaria”, „Przegląd Nauk Historycznych" 10 (2011) fasc. 2, 5-25.

Koкoszko M. - Wolińska T., Zaopatrzenie Konstantynopola w żywność, w: Konstantynopol - Nowy Rzym. Miasto i ludzie w okresie wczesnobizantyńskim, red. M.J. Leszka - T. Wolińska, Warszawa 2011, 462-470.

Kокоszко M., Ryby i ich znaczenie w życiu codziennym ludzi późnego antyku i wczesnego Bizancjum (III-VII w.), Łódź 2005.

Koкoszko M., Smaki Konstantynopola, w: Konstantynopol - Nowy Rzym. Miasto i ludzie w okresie wczesnobizantyńskim, red. M.J. Leszka - T. Wolińska, Warszawa 2011, 471-575.

KowalewsKa M. - Szczur P., Klemens Aleksandryjski, PEF V 637-641.

LAZENBy J.F., Logistics in Classical Greek Warfare, „War in History” 1 (1994) fasc. 3, 3-18.

LEYERLE B., Clement of Alexandria on the Importance of Table Etiquette, JECS 3 (1995) fasc. 2, 123-141. 
Łucarz S., Grób czy światynia? Problematyka cielesności w antropologii Klemensa Aleksandryjskiego, Kraków 2007.

ŁuKAszewicz A., Egipt Greków i Rzymian, Warszawa 2006.

Mazoye M. - Roudart L., A History of World Agriculture. From the Neolithic Age to Current Crisis, transl. J.H. Membrez, London - Sterling 2006.

Mazzini I., Diet and Medicine in the Ancient World, w: Food. A Culinary History from Antiquity to the Present, under the direction of J.-L. Flandrin - M. Montanari; Eng. ed. A. Sonnenfeld, New York - Chichester 1999, 141-152.

McCorriston J., Wheat, w: The Cambridge World History of Food, vol. 1, ed. K.F. Kiple - K.C. Ornelas, Cambridge 2000, 158-174.

Miller N.F. - Wetterstrom W., The Beginnings of Agriculture: The Ancient Near East and North Africa, w: The Cambridge World History of Food, vol. 2, ed. K.F. Kiple K.C. Ornelas, Cambridge 2000, 1123-1139.

Moritz L.A., ,, Corn”, CQ 5 (1955) fasc. 3/4, 135-141.

Moritz L.A., Grain Mills and Flour in Classical Antiquity, Oxford 1958.

Moritz L.A., Husked and „,Naked” Grain, CQ 5 (1955) fasc. 3/4, 129-134.

Muckle J.T., Clement of Alexandria on Philosophy as a Divine Testament for the Greeks, „Phoenix” 5 (1951) fasc. 3/4, 79-86.

Naumowicz J., Środowisko aleksandryjskie i pisarze III wieku, LGS II 1079-1082.

Naumowicz J., Wstęp, w: Klemens Aleksandryjski, Który człowiek bogaty może być zbawiony?, tłum. J. Czuj, wstęp i oprac. J. Naumowicz; Pseudo-Klemens, Zachęta do wytrwałości, thum. i oprac. J. Naumowicz, Kraków - Ząbki 1995, 5-32.

Neel D.E. - Pugh J.A., Jedzenie i uczty Jezusa. Kulinarny świat Palestyny pierwszego wieku, tłum. M. Król, Kraków 2014.

Nesbitt M. - Delwen S., Wheat Domestication. Archaeobotanical Evidence, „Science” (1998) vol. 279, 1433.

Nesbitt M., Grains, w: The Cultural History of Plants, ed. G. Prance - M. Nesbitt, New York - London 2005, 45-60.

Nesbitt M., Plants and People in Ancient Anatolia, „The Biblical Archaeologist” 58 (1995) fasc. 2, 68-81.

NiEMIRSKA-PlisZcZyŃSKa J., Wstęp, w: Klemens Aleksandryjski, Kobierce zapisków filozoficznych dotyczacych prawdziwej wiedzy, tłum., wstęp i kom. J. Niemirska-Pliszczyńska, t. 1, Warszawa 1994, VII-XI (Życie Klemensa Aleksandryjskiego).

Nutton V., Ancient medicine, New York - London 2004.

Nutton V., Galen and Egypt, w: Galen und das hellenistische Erbe. Verhandlungen des $I V$. Internationalen Galen-Symposiums veranstaltet vom Institut für Geschichte der Medizin (Charité) der Humboldt-Universität zu Berlin, 18.-20. September 1989, hrsg. J. Kollesch - D. Nickel, Stuttgart 1993, 11-31.

Nutton V., Galen and Medical Autobiography, „Proceedings of the Cambridge Philosophical Society" 18 (1972) 50-62.

Nutton V., Galen and the Traveler's Fare, w: Food in Antiquity, ed. J. Wilkins - D. Harvey - M. Dobson, Exeter 1999, 359-370.

Nutton V., Galen in the Eyes of His Contemporaries, „Bulletin of the History of Medicine" 58 (1984) fasc. 3, 315-324.

Nutton V., Galen of Pergamum, w: Brill's New Pauly. Encyclopaedia of the Ancient World, vol. 5, ed. H. Cancik - H. Schneider, Leiden - Boston 2004, 654-661.

Nutton V., The Chronology of Galen's Early Career, CQ 23 (1973) 158-171.

Oliver G.J., War, Food, and Politics in Early Hellenistic Athens, Oxford - New York 2007. 
Osborn E., Clement of Alexandria, Cambridge 2005.

Osborne R., Classical Landscape with Figures. The Ancient Greek City and its Countryside, London 1987.

OsmańsKi M., Filon z Aleksandrii, PEF III 440-449.

Ossowski J., Czy bogacz może być zbawiony? Uwagi na marginesie traktatu Klemensa z Aleksandrii, „Pieniądze i Więź” (1998) fasc. 1, 21-24.

PaŁucki J., Chrześcijanie wobec dóbr materialnych. Stanowisko Klemensa Aleksandryjskiego, „Cywilizacja” (2007) nr 20, 178-190.

PaŁucKi J., Dobre bogactwo, Lublin 1992.

PAncerz R.M., Chrześcijanin a dobra materialne w refleksji Szkoły Aleksandryjskiej. Od Klemensa do Dydyma, VoxP 32 (2012) t. 57, 483-493.

Perlès C., The Early Neolithic in Greece. The First Farming Communities in Europe, Cambridge 2001.

Prioreschi P., A History of Medicine, vol. 3: Roman Medicine, Omaha 1998.

Purcell N., The Way We Used to Eat. Diet, Community, and History at Rome, „The American Journal of Philology" 124 (2003) fasc. 3, 329-358.

Quick R. - Simon S.J., Wheat Production and the Romanization of Northern Gaul, „The Ancient World" 30 (1999) fasc. 1, 59-62.

Reger G., The Public Purchase of Grain on Independent Delos, „Classical Antiquity” 12 (1993) 2, 300-334.

Rickman G.E., The Grain Trade under the Roman Empire, „Memoirs of the American Academy in Rome" 36 (1980) 261-275.

Rotroff S.I. - OAkley J.H., Debris from a Public Dining Place in the Athenian Agora, Princeton 1992.

Russo L., Zapomniana rewolucja. Grecka myśl naukowa a nauka nowoczesna, tłum. I. Kania, Kraków 2005.

SADY W., Czy uczeni aleksandryjscy byli naukowcami?, „Zagadnienia Naukoznawstwa” 43 (2007) fasc. 2, 293-302.

Samuel D., Bread in Archaeology, „Civilisations” 49 (2002) fasc. 1/2, 27-36.

SARTON G., Galen of Pergamon, Lawrence 1954.

Scarborough J., Dioskourides of Anazarbos, w: The Encyclopedia of Ancient Natural Scientists. The Greek Tradition and its Many Heirs, ed. P. Keyser - G.L. Irby-Massie, Milton Park - New York 2008, 271-273.

ScArborough J., Galen and the Gladiators, „Episteme” 5 (1971) 98-111.

Scarborough J., Hērophilos of Khalkēdōn, w: The Encyclopedia of Ancient Natural Scientists. The Greek Tradition and its Many Heirs, ed. P. Keyser - G.L. Irby-Massie, Milton Park - New York 2008, 387-390.

Scarborough J., Oreibasios of Pergamon, w: The Encyclopedia of Ancient Natural Scientists. The Greek Tradition and its Many Heirs, ed. P. Keyser - G.L. Irby-Massie, Milton Park - New York 2008, 595-596.

Semple E.Ch., Ancient Mediterranean Agriculture. Part I, „Agricultural History” 2 (1928) fasc. 2, 61-98.

Semple E.Ch., Ancient Mediterranean Agriculture. Part II. Manuring and Seed Selection, „Agricultural History” 2 (1928) fasc. 3, 129-156.

Semple E.Ch., Geographic Factors in the Ancient Mediterranean Grain Trade, „Annals of the Association of American Geographers" 11 (1921) 47-74.

Shaw T.M., Vegetarianism, Heresy, and Asceticism in Late Ancient Christianity, w: Eating and Believing. Interdisciplinary Perspectives on Vegetarianism and Theology, ed. D. Grumett - R. Muers, London 2008, 75-88. 
Siorek T., Elementy etyki seksualnej w „Pedagogu” Klemensa Aleksandryjskiego, TPatr 5 (2008) 169-190.

SiRKs A.J.B., The Size of the Grain Distribution in Imperial Rome and Constantinople, „Athenaeum” 79 (1971) 215-237.

SŁomka J., Ciało i krew Jezusa jako pokarm. J 6,48-58 w interpretacji Klemensa Aleksandryjskiego, SSHT 37 (2004) fasc. 2, 131-138.

Stownik pisarzy antycznych, red. A. Świderkówna, Warszawa 2001.

Sмітн B.D., The Emergence of Agriculture, New York 1995.

Solomon J., ,, Tracta”. A Versatile Roman Pastry, „Hermes” 106 (1978) fasc. 4, 539-556.

Sparkes B.A., The Greek Kitchen, „The Journal of Hellenic Studies” 82 (1962) 121-137.

SzARmach M., Klemens Aleksandryjski O słowach nieprzyzwoitych, „Terminus” 12 (2010) fasc. 1, 221-224.

Szarmach M., O pewnej dygresji u Klemensa Aleksandryjskiego. (Czemu poświęca się czas: Paedagogus III 26-30), VoxP 28 (2008) t. 52/2, 1065-1068.

Szarmach M., Wstęp, w: Klemens Aleksandryjski, Wychowawca, thum., wstęp i kom. M. Szarmach, Toruń 2012, 7-11.

Szczur P., Chrześcijanie wobec bogactwa w nauczaniu Klemensa Aleksandryjskiego, „Archiwa, Biblioteki i Muzea Kościelne" 98 (2012) 393-406.

Szczur P., Czy człowiek bogaty może być zbawiony? Stanowisko Klemensa Aleksandryjskiego, TPatr 10 (2013) 43-56.

SzczUR P., Vetera et nova $w$ koncepcji aretologii Klemensa Aleksandryjskiego, RT 53 (2006) z. 4, 87-105.

SzczUr P., Wiara matka miłości chrześcijańskiej wedtug Klemensa Aleksandryjskiego, VV 5 (2004) 129-144.

Szczur P., Wplyw starożytnej myśli greckiej na kształtowanie się koncepcji roztropności

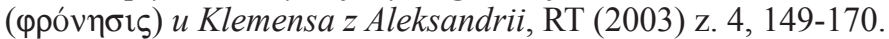

SzymusiaK J.M., Klasycyzm Klemensa Aleksandryjskiego, STV 9 (1971) fasc. 1, 289-302.

Świderek J., Metody medycyny naukowej w ujęciu Galena, „Zagadnienia Naukoznawstwa" 43 (2007) fasc. 2, 239-248.

Świderkówna A., Hellenika. Wizerunek epoki od Aleksandra do Augusta, Warszawa 2009.

Thorndike L., Galen. The Man and His Times, „The Scientific Monthly” 14 (1922) fasc. $1,83-93$.

Toussaint-Samat M., Historia naturalna i moralna jedzenia, tłum. A.B. Matusiak M. Ochab, Warszawa 2008.

Tsoukala V., Cereal Processing and the Performance of Gender in Archaic and Classical Greece: Iconography and Function of a Group of Terracotta Statuettes and Vases, w: SOMA 2007. Proceedings of the XI Symposium on Mediterranean Archaeology, Istanbul Technical University, 24 and 29 April 2007, ed. Çiğdem Özkan Aygün, Oxford 2009, 387-395.

Valamoti S.-M., Investigating the Prehistoric Bread of Northern Greece. The Archaeobotanical Evidence for the Neolithic and the Bronze Age, „Civilisations” 49 (2002) fasc. $1 / 2,49-66$.

Vidal Manzanares C., Pisarze wczesnochrześcijańscy I-VII w., thum. E. Burska, Warszawa $2001^{2}$.

Vogt S., Drugs and Pharmacology, w: The Cambridge Companion to Galen, ed. R.J. Hankinson, Cambridge - New York 2008, 304-322.

Wagner W., Another Look at the Literary Problem in Clement of Alexandria's Major Writings, ChH 37 (1968) fasc. 3, 251-260. 
Westgate R., Space and Social Complexity in Greece from the Early Iron Age to the Classical Period, „Hesperia” 84 (2015) fasc. 1, 47-95.

Whiтвy M., The Grain Trade of Athens in the Fourth Century BC, w: Trade, Traders, and the Ancient City, ed. H. Parkins - Ch. Smith, London - New York 1998, 99-124.

Wilkins J.M. - Hill Sh., Food in the Ancient World, Malden - Oxford 2006.

WiLkins J.M., Foreword, w: Galen, On the properties offoodstuffs (De alimentorum facultatibus), transl. O. Powell, Cambridge 2003, IX-XXI.

Wilkins J.M., The Boastful Chef. The Discourse of Food in Ancient Greek Comedy, Oxford 2000.

Willcox G., The Beginnings of Cereal Cultivation and Domestication in Southwest Asia, w: A Companion to the Archaeology of the Ancient Near East, vol. 1, ed. D.T. Potts, Oxford 2012, 163-180.

WinNiczuk L., Chleb u starożytnych Greków i Rzymian, „Meander” 5 (1950) 224-242.

WitT R.E., The Hellenism of Clement of Alexandria, CQ 25 (1931) fasc. 3/4, 195-204.

Wojtczak J., Stosunek Klemensa Aleksandryjskiego do filozofii wedtug Stromata, STV 9 (1971) fasc. 1, 263-288.

ZAGÓRSKi D., „Miara wszystkich rzeczy jest Bóg”. Platońska zasada w interpretacji Klemensa Aleksandryjskiego, RT (2003) z. 4, 245-255.

Zagórski D., Dzieje Apostolskie w wykładzie „,Kobierców” Klemensa Aleksandryjskiego, „Biblica et Patristica Thoruniensia” 1 (2008) 263-278.

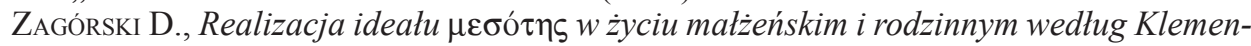
sa Aleksandryjskiego, RT 52 (2005) z. 4, 5-24.

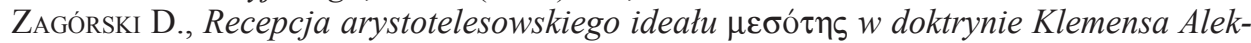
sandryjskiego. Problem definicji, RT 51 (2004) z. 4, 5-42.

Zagónski D., Troska o ciało w „Pedagogu” Klemensa Aleksandryjskiego, PChr 2 (2005) 29-37.

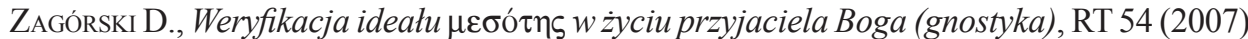
Z. 4, 99-121.

Zeder M.A., The Origins of Agriculture in the Near East, "Current Anthropology” 52 (2011) Supplement 4, S221-S235.

ZIELIŃSKi J., Filozofia Logosu jako alegoretyczna hermeneutyka. Klemens Aleksandryjski, „Theologica Wratislaviensia” 1 (2006) 99-107.

Zohary D. - Hopf M., Domestication of Plants in the Old World. The Origin and Spread of Cultivated Plants in West Asia, Europe and in the Nile Valley, Oxford 1993.

Zohary D., The Mode of Domestication of the Founder Crops of Southwest Asian Agriculture, w: The Origins and Spread of Agriculture and Pastoralism in Eurasia, ed. D.R. Harris, London 1996, 142-158. 
